$$
\text { DOE/NTP--96-1202 }
$$

\title{
Mobile Systems Capability Plan
}

Expediting the Work of Preparing TRU Waste for Disposal

\author{
Carlsbad Area Office \\ U.S. Department of Energy
}

September 1996 


\title{
Mobile Systems Capability Plan
}

Expediting the Work of Preparing TRU Waste for Disposal

\author{
Carlsbad Area Office \\ U.S. Department of Energy
}

September 1996

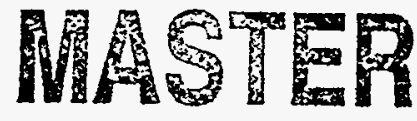

$H H$ 


\section{DISCLAIMER}

Portions of this document may be illegible in electronic image products. Images are produced from the best available original document. 


\section{DISCLAIMER}

This report was prepared as an account of work sponsored by an agency of the United States Government. Neither the United States Government nor any agency thereof, nor any of their employees, makes any warranty, express or implied, or assumes any legal liability or responsibility for the accuracy, completeness, or usefulness of any information, apparatus, product, or process disclosed, or represents that its use would not infringe privately owned rights. Reference herein to any specific commercial product, process, or service by trade name, trademark, manufacturer, or otherwise does not necessarily constitute or imply its endorsement, recommendation, or favoring by the United States Government or any agency thereof. The views and opinions of authors expressed herein do not necessarily state or reflect those of the United States Government or any agency thereof. 
Mobile Systems Capability Plan

War W Sthoun for KENT Huntre

Manager, Office of National TRU Waste Operations

Date: $9 / 30 / 96$

Prepared by the

U.S. Department of Energy, Carlsbad Area Office

September 30, 1996 


\section{RECORD OF CURRENT REVISIONS/CHANGE NUMBER BY PAGE}

\section{PAGE NUMBER REVISION NUMBER}




\section{RECORD OF CURRENT REVISIONS/CHANGE ENTRIES}

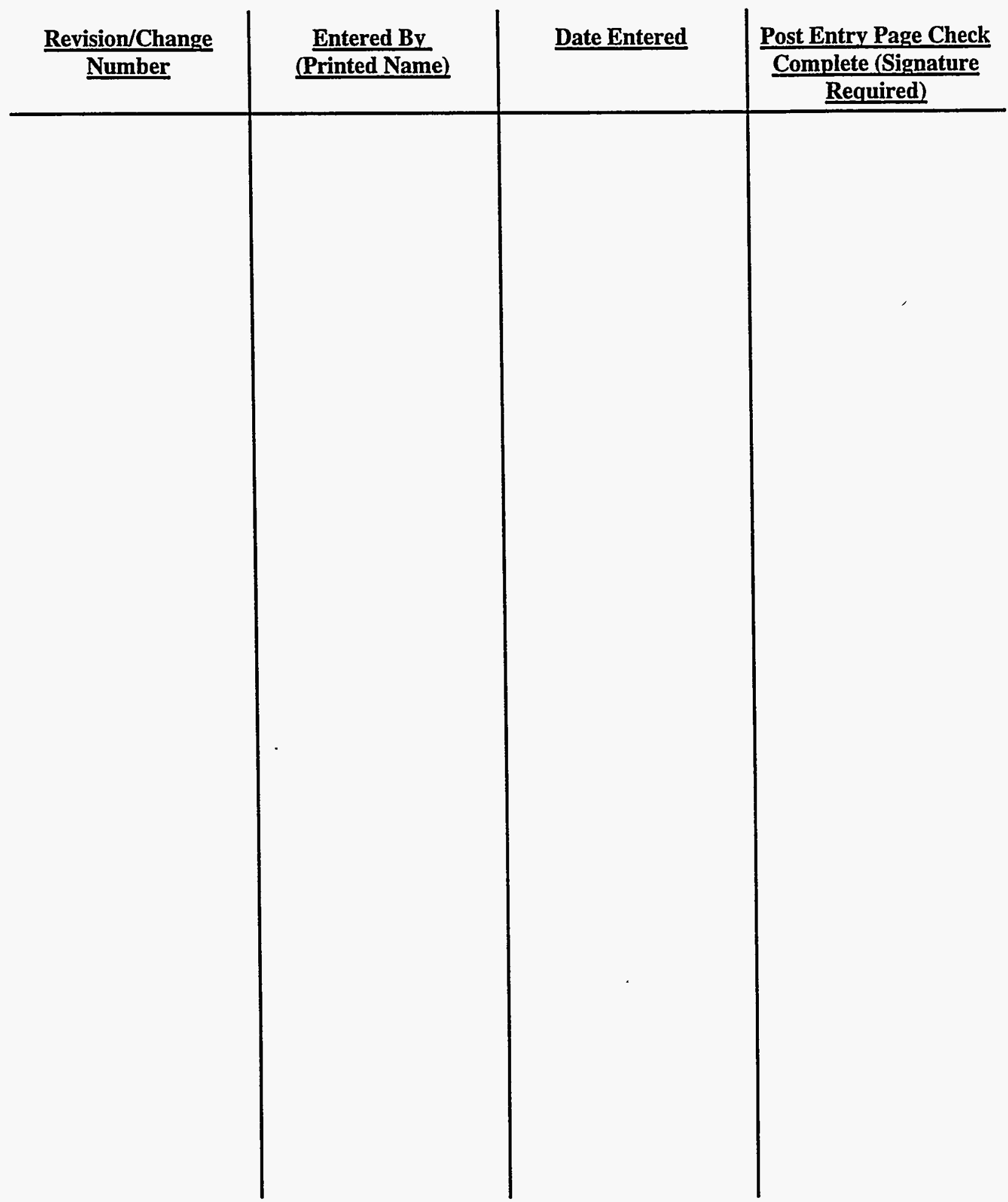

NOTE: Instructions for the completion of this form will be supplied with each transmission of a revision/change. 
The success of the mobile system initiative described in this plan will depend upon the efforts of many people both within the DOE complex and in the private sector.

With the preparation of this plan, we have made a good beginning: many people contributed their time to gathering the data needed to conduct careful analyses. In particular we want to acknowledge the efforts of DOE site personnel and commercial vendors of mobile waste systems. We look forward to a productive partnership with them. 


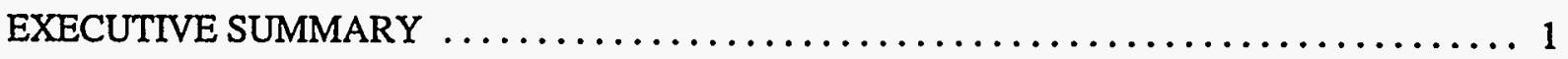

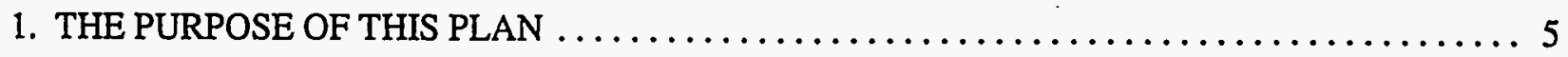

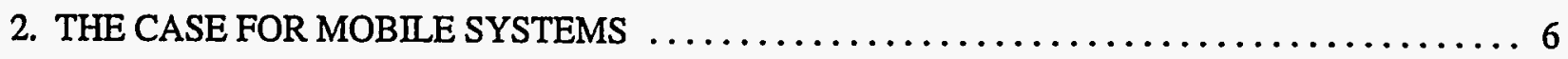

\section{BACKGROUND INFORMATION}

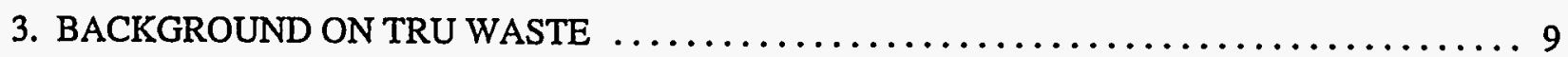

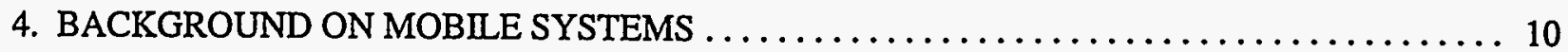

5. PLANNING ASSUMPTIONS, SCOPE, AND METHODS $\ldots \ldots \ldots \ldots \ldots \ldots \ldots \ldots$

6. BACKGROUND ON DOE'S INVESTIGATIONS OF MOBILE SYSTEMS $\ldots \ldots \ldots \ldots \ldots \ldots$

\section{REQUIREMENTS, NEEDS, AND CAPABLITIES}

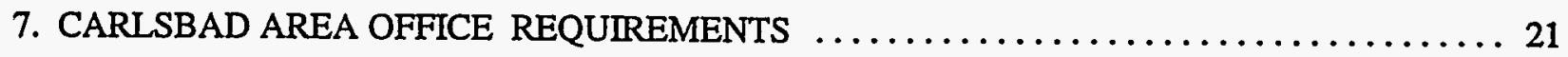

8. THE SITE REQUIREMENTS THAT MOBILE SYSTEMS MUST MEET $\ldots \ldots \ldots \ldots \ldots \ldots 24$

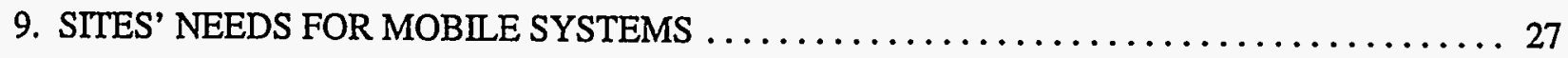

10. MOBILE SYSTEM CAPABILITIES: EXISTING AND UNDER DEVELOPMENT . . . . . . 35

\section{DEPLOYMENT}

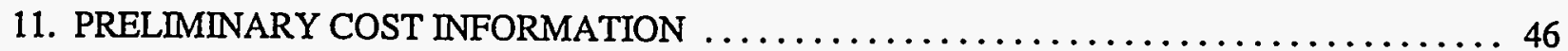

12. OPTIONS FOR ACQUIRING MOBILE SYSTEM SERVICES $\ldots \ldots \ldots \ldots \ldots \ldots \ldots \ldots$

13. FOR VENDORS: STEPS TOWARD DOE CONTRACTS $\ldots \ldots \ldots \ldots \ldots \ldots \ldots \ldots$

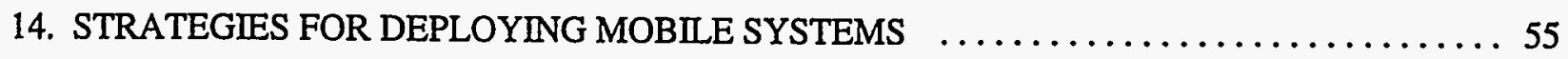




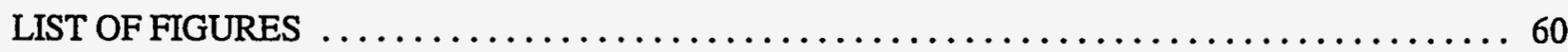

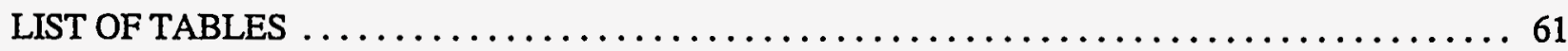

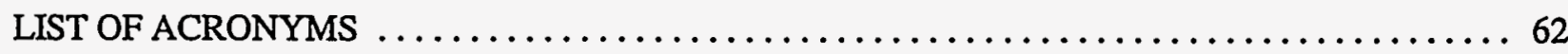

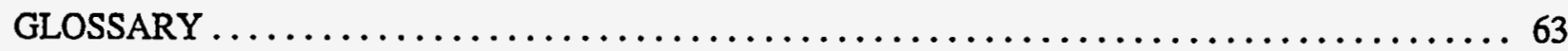

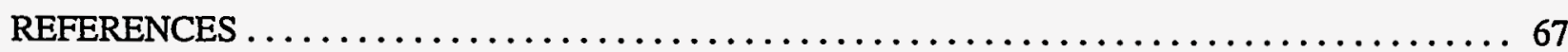

APPENDIX A

CARLSBAD AREA OFFICE ORGANIZATION CHART $\ldots \ldots \ldots \ldots \ldots \ldots \ldots \ldots$ A-1

APPENDIX B

INVENTORIES OF CONTACT-HANDLED TRU WASTE $\ldots \ldots \ldots \ldots \ldots \ldots \ldots \ldots$ B-1

APPENDIX C

MOBILE SYSTEMS CAPABILITY CHECKLIST $\ldots \ldots \ldots \ldots \ldots \ldots \ldots \ldots \ldots \ldots$ C-1 


\section{Meeting a key DOE goal}

The Carlsbad Area Office of the U.S. Department of Energy (DOE) has prepared this Mobile Systems Capability Plan to initiate contracting for and deployment of mobile system services to expedite the work of preparing transuranic (TRU) waste for disposal.

One hundred two-thousand cubic meters of retrievably stored, contact-handled TRU waste are in inventory at numerous sites around the country.' (Figure ES- 1 identifies where these sites are located.) In addition, an estimated 38,000 cubic meters of TRU waste will be generated in the course of waste inventory work-off and continuing DOE operations. All defense-generated TRU waste is destined for permanent disposal in the Waste Isolation Pilot Plant (WIPP) near Carlsbad, New Mexico.

WIPP is scheduled to open in November 1997, pending receipt of regulatory approvals from the U.S. Environmental Protection Agency (EPA) and the State of New Mexico. To meet the DOE goal of disposing of as much TRU waste as possible by the end of Fiscal Year 2006, the Carlsbad Area Office has prepared the National Transuranic Waste Management Plan. This logistical plan integrates and optimizes waste work-off and shipping schedules across all TRU waste sites.

To ship TRU waste to WIPP, sites must first certify that the waste meets WIPP Waste Acceptance Criteria. ${ }^{2}$ This in turn means that the waste must be characterized to determine its chemical, radiological, and physical attributes. Wastes that do not meet acceptance criteria may be subject to additional processing, including repackaging for shipment in TRUPACT-II shipping containers, before disposal at the WIPP.

Most sites with significant quantities of TRU waste plan to use existing fixed facilities or open new ones between Fiscal Years 1997 and 2006 to perform these functions, but the new facilities will come on line gradually and there will be a lag time until the "pipeline" to WIPP is filled. Expanding fixed facility capacity will be difficult: DOE funding is limited; the Federal budget process requires at least a two-year lead time; and once funds are appropriated, it takes time to construct fixed facilities.

Small-quantity sites lack the capability to characterize, treat, package, and load TRU waste. They do not plan to build fixed facilities. While these sites together store less than 1 percent of TRU waste inventories, they represent far more than 1 percent of the costs, responsibilities, and potential risks associated with managing TRU waste.

\section{Benefits of using mobile systems provided by commercial vendors}

An alternative to fixed facilities is the use of mobile systems mounted in one or more trailers, or mounted on skids and transported to a site. Mobile systems will be used for all characterization and certification

\footnotetext{
'All inventory data in this report are taken from the National Transuranic Waste Management Plan, Revision 0 , DOENTTP-96-1204, DOE-Carlsbad Area Office, 1996.

${ }^{2}$ Waste Acceptance Criteria for the Waste Isolation Pilot Plant, DOE/WIPP-069, DOE-Carlsbad Area Office, 1996.
} 
methods at small-quantity sites. Large-quantity sites can also use mobile systems to characterize, process, repackage, or load TRU waste in shipping containers.

The Carisbad Area Office intends to pursue a strategy of privatization of mobile system services through performance-based, fixed-price contracts to offer the DOE complex substantial advantages:

- To acquire mobile system services from vendors, DOE can use operating funds that are already in hand. To acquire fixed facilities, it must use capital equipment funds, which require at least a two-year lead time.

- Mobile systems can be deployed more rapidly than fixed facilities can be constructed.

- There will be associated reductions in mortgage costs, particularly for the numerous sites storing small quantities of TRU waste, and reductions in potential risk across the DOE complex.

- There will be greater flexibility in managing and configuring waste preparation in the near- and long-term.

- There will be greater efficiencies and cost-effectiveness in waste preparation.

\section{Focus}

Mobile systems will have a variety of applications over an extended period of time. However, this plan is focused on contact-handled TRU waste for the first 10 years of WIPP's operation. Although some DOE sites have developed mobile system capabilities, these systems are limited in number, tend to be sitespecific, and by nature do not offer the advantages of privatization. Therefore the plan also focuses on commercial vendors.

The information and conclusions in the plan are derived from: the review of prior studies; identification of Carlsbad Area Office and DOE site requirements that mobile systems must meet; review of the National Transuranic Waste Management Plan to determine sites' needs for mobile services; the survey of vendors and DOE sites to determine their mobile capabilities and the status, throughput rate, and costs of their equipment; discussions with vendors and custodians of DOE-owned mobile systems to learn about demonstrations of mobile system technologies at DOE sites; and consideration of the benefits of deploying mobile systems at each site for more than 10 years.

To indicate the possible magnitude of the costs of deploying mobile systems, preliminary estimates of equipment, maintenance, and operating costs over a 10-year period were prepared, and options for acquiring mobile systems through purchase, lease, and privatization through fixed-price contracts were considered.

\section{Findings}

As documented in the National Transuranic Waste Management Plan, sites need mobile capabilities, and those capabilities are available in the marketplace. The challenge is making the match between needs and 
capabilities-quickly and on terms that are cost-effective. The substantial benefits that mobile systems offer can be realized as DOE recognizes and responds to private sector needs for:

- a central point of contact within DOE to which they can provide information about their capabilities and from which they can obtain guidance on site needs and requirements;

- a minimum of required paperwork, and rapid turnaround on review and approval of required documentation and contract mechanisms;

- a clear definition of what is required to meet the requirements of the WIPP Waste Acceptance Criteria; and

- a clear definition of what is required to meet the high standard that sites have set for safe operations and full regulatory compliance within their boundaries.

Other opportunities for meeting site needs lie in development of technologies that can expand the suite of mobile capabilities. Still others may lie within the DOE complex itself: although sites' mobile capabilities are at present limited, some sites may be able to share what they have. 


\section{TRU WASTE GENERATOR/STORAGE SITES}

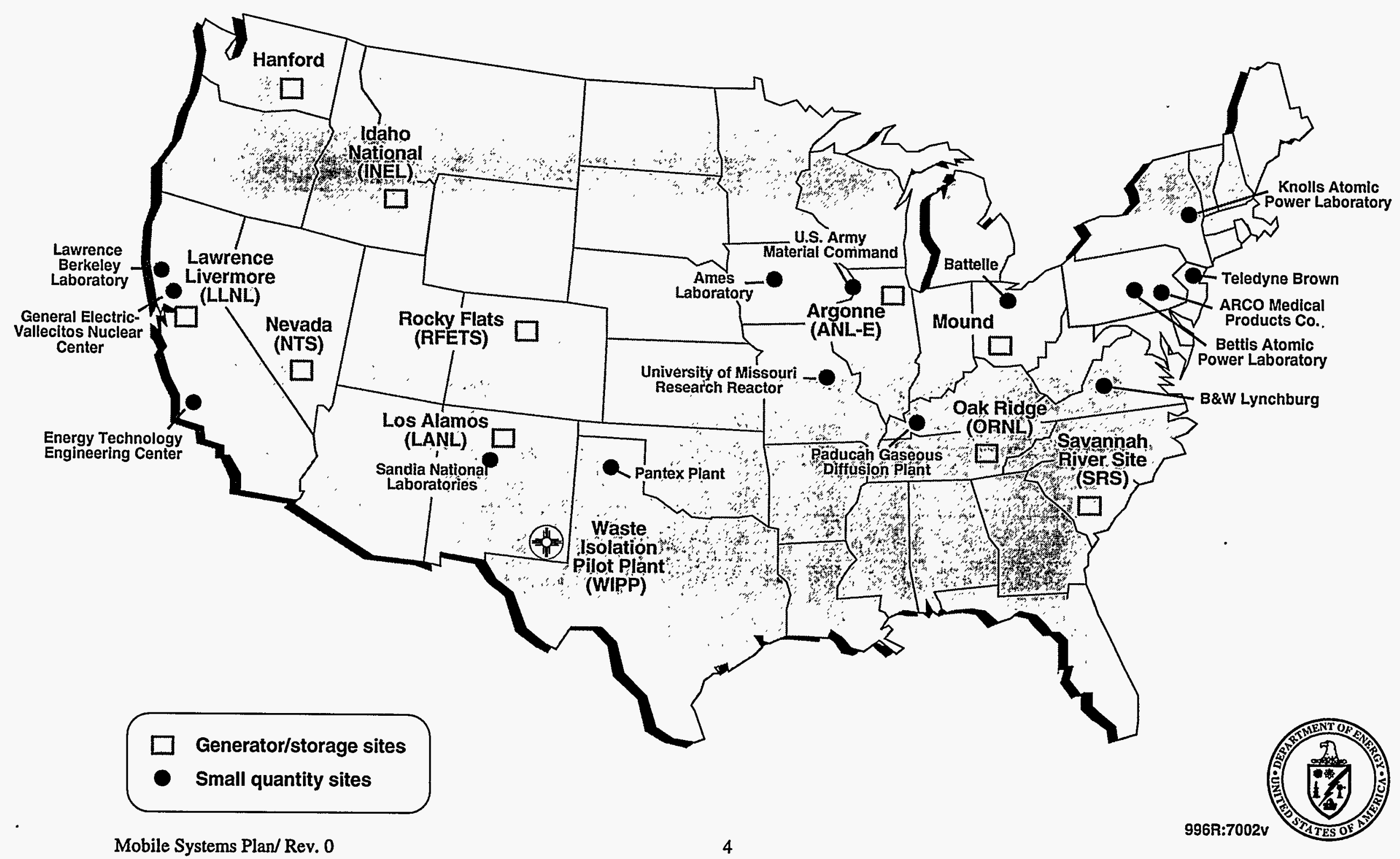




\section{THE PURPOSE OF THIS PLAN}

The Carlsbad Area Office developed this Mobile Systems Capability Plan to initiate contracting for and deployment of mobile system services to prepare TRU waste for disposal at WIPP.

The plan was developed by examining the need for mobile systems, the capabilities that exist or are being developed to meet those needs, and the issues involved in deploying them.

The plan is intended to serve several purposes:

- It will help the Carlsbad Area Office and DOE site managers determine how best to use mobile systems to meet the schedule for waste shipments to WIPP.

- By using this approach to deploying mobile systems, the Carisbad Area Office can elicit information from sites and vendors of mobile systems that further planning and implementation.

- For sites, it offers a source of information on the nature, availability, and costs of mobile services.

- For vendors, it can serve as a source of information on potential opportunities to provide mobile services.

- For stakeholders, it offers a source of information on DOE's approach to expediting TRU waste shipments and reducing mortgage costs.

This plan furthers a mobile system initiative that is still evolving. Accordingly, comments on it and suggestions on how to best realize the substantial benefits mobile systems offer are welcome from all parties. Comments should be directed to:

Manager - Waste Characterization

Carlsbad Area Office

U.S. Department of Energy

PO Box 3090, MS-560

Carlsbad, New Mexico 88221 
DOE/NTP-96-1202, Rev.0

\section{THE CASE FOR MOBILE SYSTEMS}

\section{The demands of WIPP's disposal schedule}

One hundred two-thousand cubic meters of retrievably stored, contact-handled transuranic waste are in inventory at numerous sites around the country ${ }^{3}$ (identified in Figure ES-1). In addition, an estimated 38,000 cubic meters of TRU waste will be generated in the course of waste inventory work-off and continuing DOE operations. All defense-generated TRU waste is destined for permanent disposal in the Waste Isolation Pilot Plant (WIPP) in Carlsbad, New Mexico.

WIPP is scheduled to open in November 1997, pending receipt of regulatory approvals from the U.S. Environmental Protection Agency and the State of New Mexico. To meet the DOE goal of disposing of as much TRU waste as possible by the end of Fiscal Year 2006, the Carisbad Area Office has prepared the National Transuranic Waste Management Plan. This logistical plan integrates and optimizes waste workoff and shipping schedules across all TRU waste sites.

To ship TRU waste to WIPP, sites must first certify that the waste meets WIPP Waste Acceptance Criteria ${ }^{4}$ The waste must be characterized to determine its chemical, radiological, and physical attributes. Wastes that do not need acceptance criteria may be subject to additional processing, including repackaging for shipment in TRUPACT-II shipping containers, before disposal at the WIPP.

Most sites with significant quantities of TRU waste plan to use existing fixed facilities or open new ones between Fiscal Years 1997 and 2006 to perform these functions, but the new facilities will come on line gradually and there will be a lag time until the "pipeline" to WIPP is filled. Expanding fixed facility capacity will be difficult: DOE funding is limited; the Federal budget process requires at least a two-year lead time; and once funds are appropriated, it takes time to construct fixed facilities.

Small-quantity sites lack the capability to characterize, treat, package, and load TRU waste. They do not plan to build fixed facilities. While these sites together store less than 1 percent of TRU waste inventories, they represent far more than 1 percent of the costs, responsibilities, and potential risks associated with managing TRU waste.

\section{Benefits of Mobile Systems}

The National Transuranic Waste Management Plan presents optimized schedules for working off TRU waste inventories, and also assumes the deployment of mobile systems to achieve the schedules.

DOE's Los Alamos National Laboratory demonstrated the effectiveness of using mobile systems to process TRU waste 10 years ago. (DOE's investigations of mobile systems are described in Chapter 6, below.) The Carlsbad Area Office is responsible for planning for TRU waste processing at small-quantity sites, and mobile systems will be used for these functions. Large-quantity sites can also use mobile systems to

\footnotetext{
${ }^{3}$ All inventory data in this report are taken from the National Transuranic Waste Management Plan, Revision 0, DOE/NTP-96-1204, DOE-Carlsbad Area Office, 1996.

${ }^{4}$ Waste Acceptance Criteria for the Waste Isolation Pilot Plant, DOE/WIPP-069, DOE-Carlsbad Area Office, 1996.

${ }^{5}$ Mobile Nondestructive Assay and Examination Instruments, J. M. Bieri and J.T. Caldwell, LA-UR-86-2189, 1986.
} 
characterize, treat, repackage, or load TRU waste in shipping containers. The increasing availability of commercial systems now makes it possible to privatize their use within the DOE complex.

Some of the more obvious benefits of mobile system deployment are as follows:

- More readily available funding. DOE can readily use operating funds to procure mobile system services from vendors. By contrast, the Federal budget process requires at least a two-year lead time for receipt of funds to acquire capital equipment.

- An accelerated schedule. Because funding is more readily available and because DOE can acquire mobile systems faster than it can build fixed facilities, mobile systems offer the fastest way for DOE sites to start preparing TRU waste for shipment to WIPP.

- Reductions in potential risk and mortgage costs. By accelerating the schedule for waste disposal, mobile systems will reduce potential risk posed by storage of TRU waste and will reduce mortgage costs throughout the $\mathrm{DOE}$ complex.

- Greater flexibility in managing TRU waste preparation. Mobile units can be deployed quickly, allowing sites to process TRU waste while waiting for fixed facilities to be funded, constructed, and declared operational. If a fixed facility is delayed, mobile systems will continue to operate without interruption. Mobile systems can also augment fixed facilities by processing inventories of various sizes. Commercial systems can be operated by either vendor or site personnel, or both, as specified by contract.

- Greater flexibility in configuring TRU waste preparation. Mobile systems can be reconfigured to meet changing needs:

- $\quad$ Multiple units of one kind of equipment can be added to reach a desired throughput level for the system, and then reduced as waste volumes decline.

- $\quad$ Equipment can be moved to different areas on the site.

- $\quad$ Equipment can be moved to different sites.

- $\quad$ After TRU waste has been prepared for shipment, the equipment may be appropriate for use with other waste streams.

- For small-quantity sites, an essential means of preparing TRU waste for shipment.

- A privatization opportunity. Privatization offers a way to avoid capital acquisition and gain greater cost-effectiveness.

These benefits provide a strong rationale for the deployment of mobile systems. 


\section{BACKGROUND INFORMATION}




\section{BACKGROUND ON TRU WASTE}

Mobile systems can be applied to a wide range of wastes:

- contact-handled TRU waste;

- remote-handled TRU waste;

- waste generated from environmental restoration and decommissioning activities; and

- low-level waste and low-level mixed wastes.

In this plan the term TRU waste includes TRU mixed waste.

This plan addresses contact-handled TRU wastes only, because the criteria and requirements necessary for certifying them have been defined. For remote-handled TRU waste, only preliminary characterization and transportation-related waste packaging requirements have been defined, and mobile characterization and treatment systems for those wastes are still in the planning stage.

Of contact-handled TRU wastes, this plan covers both those that are retrievably stored and those newly generated. The Carlsbad Area Office Transuranic Waste Characterization Quality Assurance Program Plan (QAPP), Revision 0, distinguishes between "retrievably stored" and "newly generated" TRU waste. Retrievably stored wastes are those that were generated before implementation of a TRU waste characterization program that meets the requirements outlined in the QAPP; newly generated wastes are those generated after the implementation of such a program.

TRU waste takes many forms. It mainly consists of debris such as paper, plastic, and cloth; scrap metal; glass; sludge from various treatment processes; and organic sludge. This waste is packaged in 55-gallon steel drums and other containers, primarily metal boxes of various sizes. The plan focuses on TRU waste packaged in 55-gallon steel drums and standard waste boxes designed for TRUPACT-II, because waste in these drums and standard waste boxes can be characterized for certification and loaded for shipment now.

The DOE Waste Treatability Group Guidance ${ }^{7}$ provides a system for grouping wastes with similar physical and chemical properties according to matrix parameter categories. These categories are divided into three broad groups: homogeneous solids (an S3000 summary category), soil/gravel (an S4000 summary category), and debris waste (an S5000 summary category). Sampling and analytical requirements described in the QAPP are based on the summary category by which the waste stream is identified. Each matrix presents its own requirements for characterization. These matrices vary widely in composition, and some are far more difficult to characterize than others. The accuracy and precision of the results of characterization can vary with the matrix. Accordingly technologies must be appropriately matched with the wastes they are intended to characterize.

${ }^{6}$ Transuranic Waste Characterization Quality Assurance Program Plan, Revision 0, CAO-94-1010, DOE-Carlsbad Area Office, 1995.

${ }^{7}$ DOE Waste Treatability Group Guidance, DOE/LLW-217, Revision 0, 1995. 


\section{BACKGROUND ON MOBILE SYSTEMS}

\section{Types of mobile systems considered}

In this plan mobile system refers to a system that is either:

- mobile, and can operate independently in one or more trailers; or

- portable, mounted on skids, and supported by facilities and services at the site.

Figures $4.1,4.2$, and 4.3 present examples of mobile systems.

\section{Functions mobile systems could perform}

In this plan the terms preparation and processing are used interchangeably to encompass the functions that must be performed in order to certify that TRU waste complies with WIPP's waste acceptance criteria.

Characterizing TRU waste is a major portion of the work of preparing TRU waste for disposal. It includes obtaining chemical, radiological, and physical data. The characterization capabilities of mobile systems matched to site needs are the following:

- nondestructive examination (NDE);

- nondestructive assay (NDA);

- visual examination;

- headspace gas sampling and analysis; and

- $\quad$ Resource Conservation and Recovery Act (RCRA) sampling and analysis.

Mobile systems could also easily be used to test the integrity of the 55-gallon drums or boxes that are retrieved from storage.

Additional site needs that can be met through mobile services are:

- treatment, such as size-reduction or immobilization;

- drum venting;

- repackaging; and

- $\quad$ loading and unloading TRU waste into TRUPACT-II shipping containers.

In support of TRU waste certification, vendors can provide other mobile services. Those listed below follow from the requirements of the QAPP and the WIPP Waste Acceptance Criteria (discussed in Chapter 7): 
- $\quad$ sampling process design;

- $\quad$ sampling;

- measurement and data acquisition/database entry; and

- data review, validation, and verification.

Other services support compliance with the WIPP Waste Acceptance Criteria Tracking and Shipment requirements:

- $\quad$ marking containers (bar-coding);

- $\quad$ preparing data packages/shipping papers;

- $\quad$ waste stream profile form preparation;

- transmitting data packages to WIPP via the WIPP Waste Information System;

- $\quad$ surveying and decontaminating waste containers;

- monitoring work area to detect contamination; and

- weighing waste containers.

Sites could also use mobile systems to meet the requirements of their RCRA permits or of the Federal Facilities Compliance Act.

The equipment that performs the functions named above can be configured in a variety of ways, and each system could be configured to contain one or more technologies that perform these waste characterization and support functions.

\section{Scenarios for deployment: large TRU waste sites}

One of the chief advantages offered by mobile systems is flexibility in deployment. They can be used to:

- augment or supplement fixed facilities;

- substitute for them; and

- bridge the gap until fixed facilities are operational.

Mobile systems could also:

- prepare large volumes of waste for shipment at a single site over a period of years;

- prepare small volumes over a shorter period of time; 
- handle waste in batches, intermittently rather than continuously;

- be moved from one location to another at the same site; and

- serve more than one site, and one site more than once.

\section{Scenarios for deployment: small-quantity sites}

Mobile systems are particularly attractive for small-quantity sites, which lack the facilities to prepare their TRU waste for shipment. These sites can either,

- perform the partial TRU-waste preparation required to ship TRU waste to large TRU waste sites for the full characterization necessary to meet WIPP waste acceptance criteria, or

- use mobile systems to fully characterize the waste for direct shipment to WIPP.

The sites will also need mobile systems to load waste into TRUPACT-II containers. 


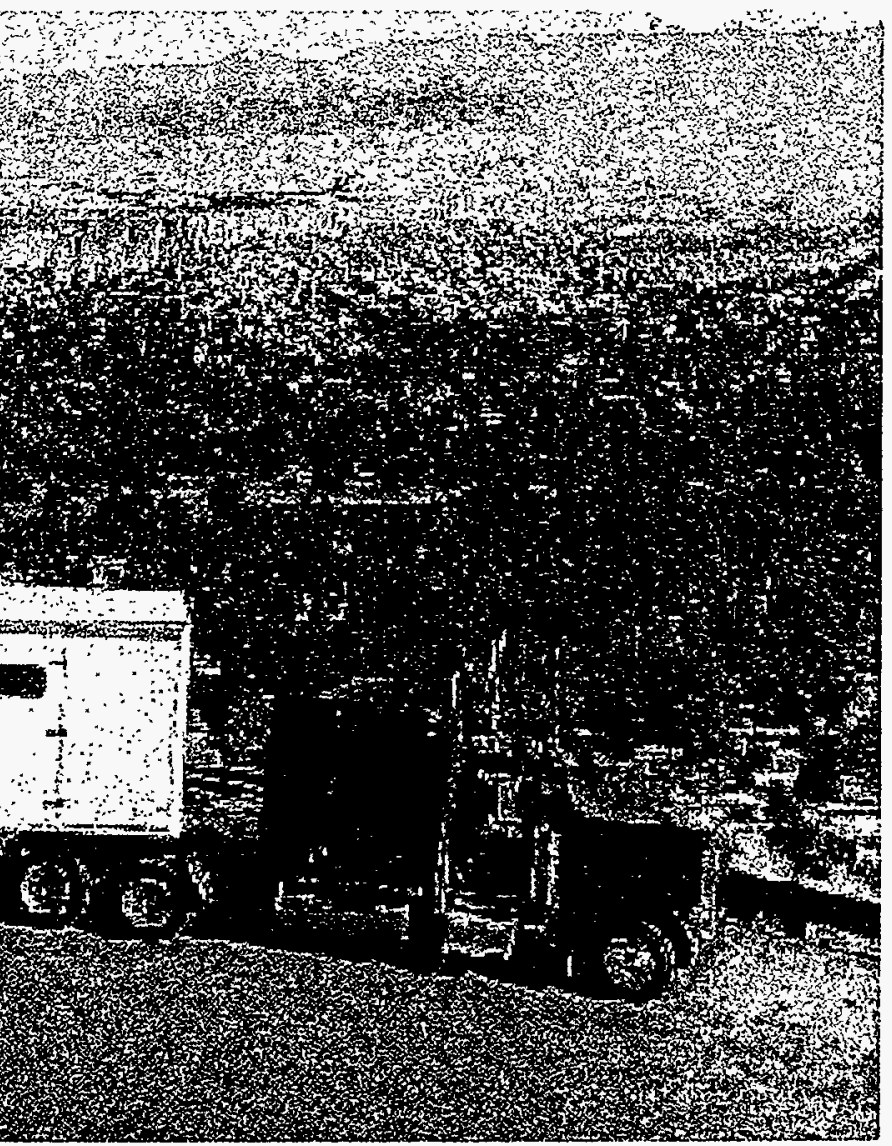

Photograph Courtesy of Pajarito Scientific Corporation

Trailer for Imaging Passive Active Neutron and Gamma Energy Analysis System

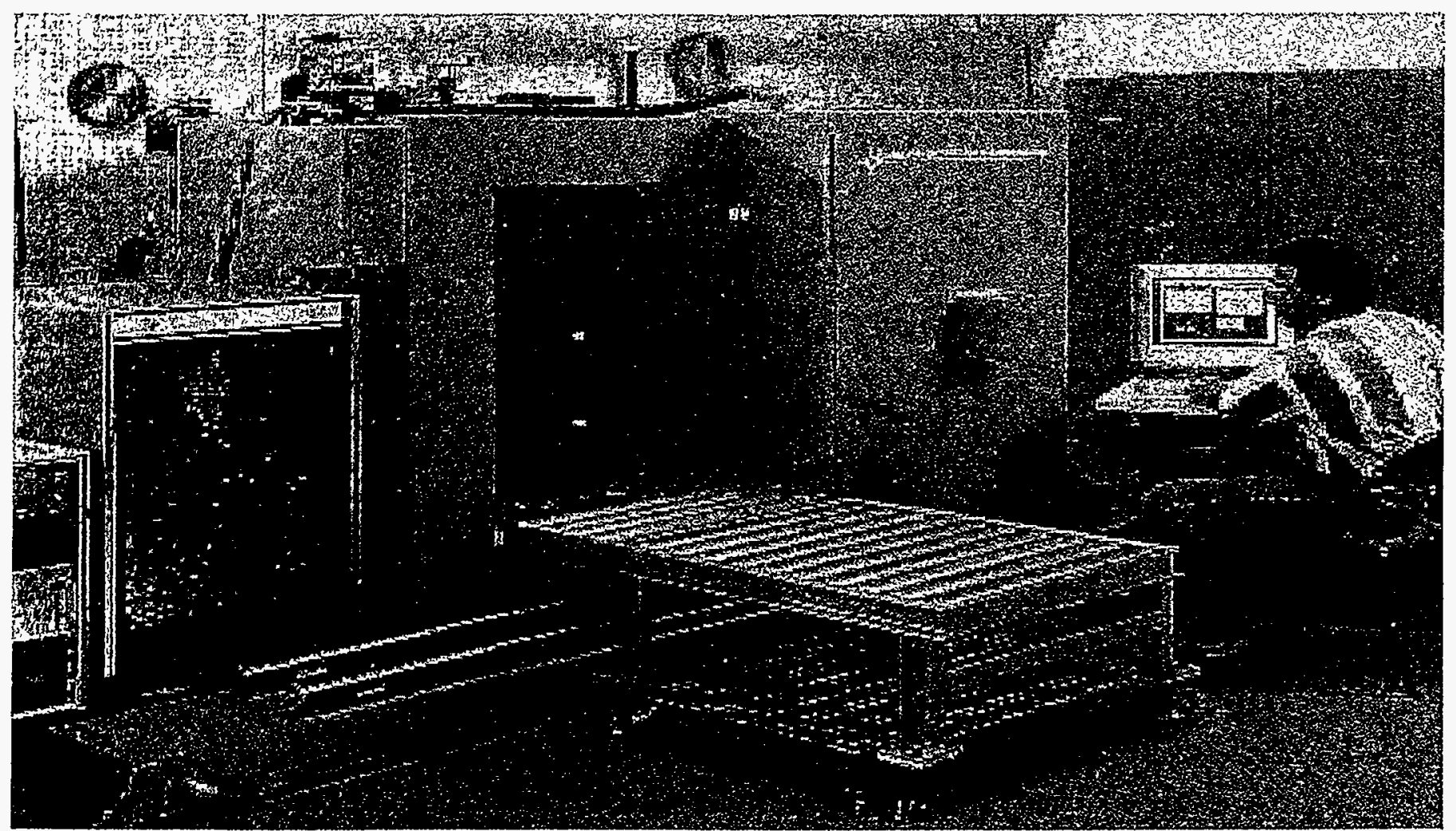

Photograph Courtesy of Pajarito Scientific Corporation

The Imaging Passive Active Neutron and Gamma Energy Analysis System Mobile Systems Plan/Rev. 0 


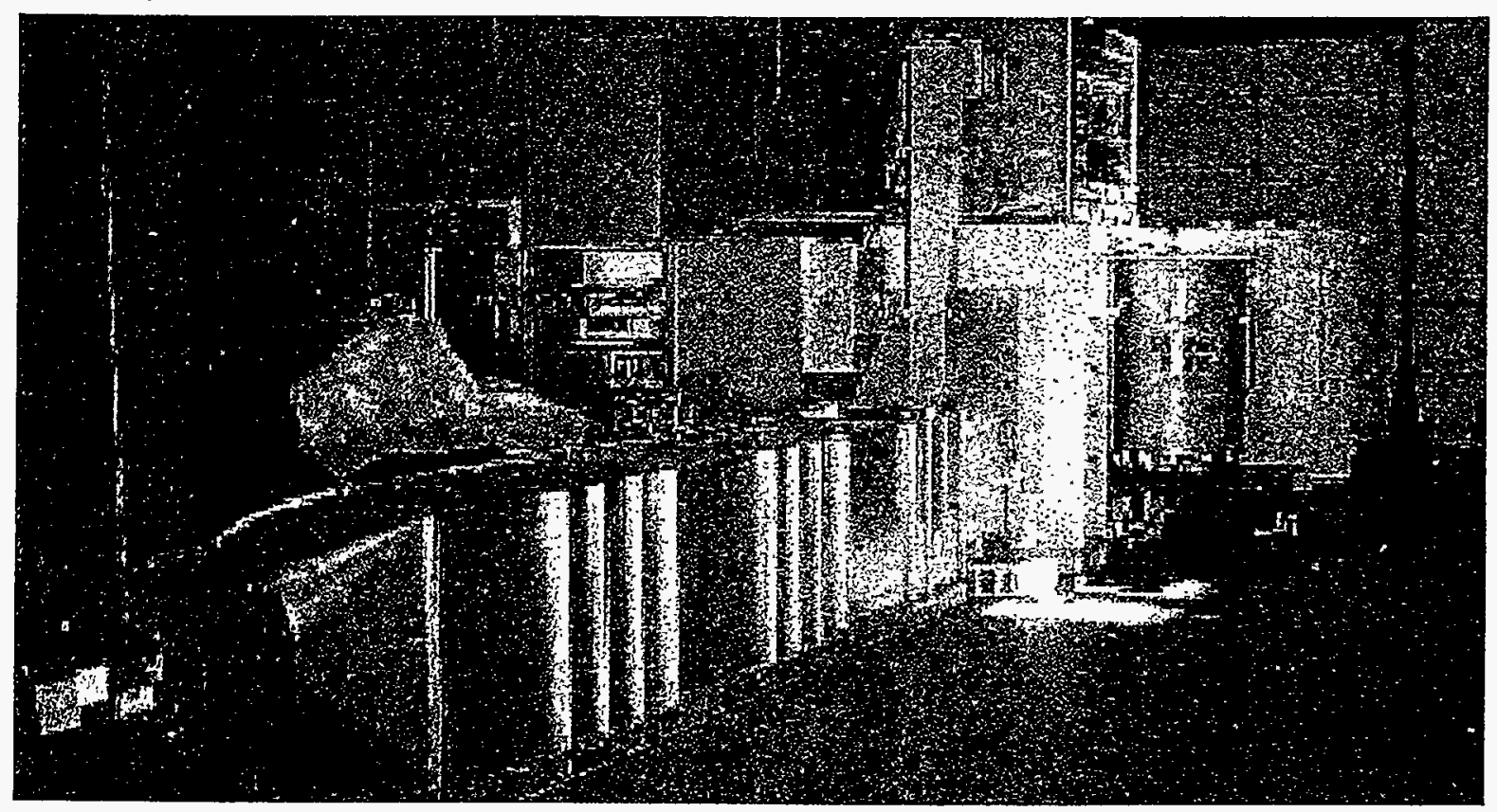

Photograph Courtesy of NFT Inc.

Figure $4.2 \mathrm{a}$

Portable Drum Venting and Headspace Gas Sampling and Analysis System

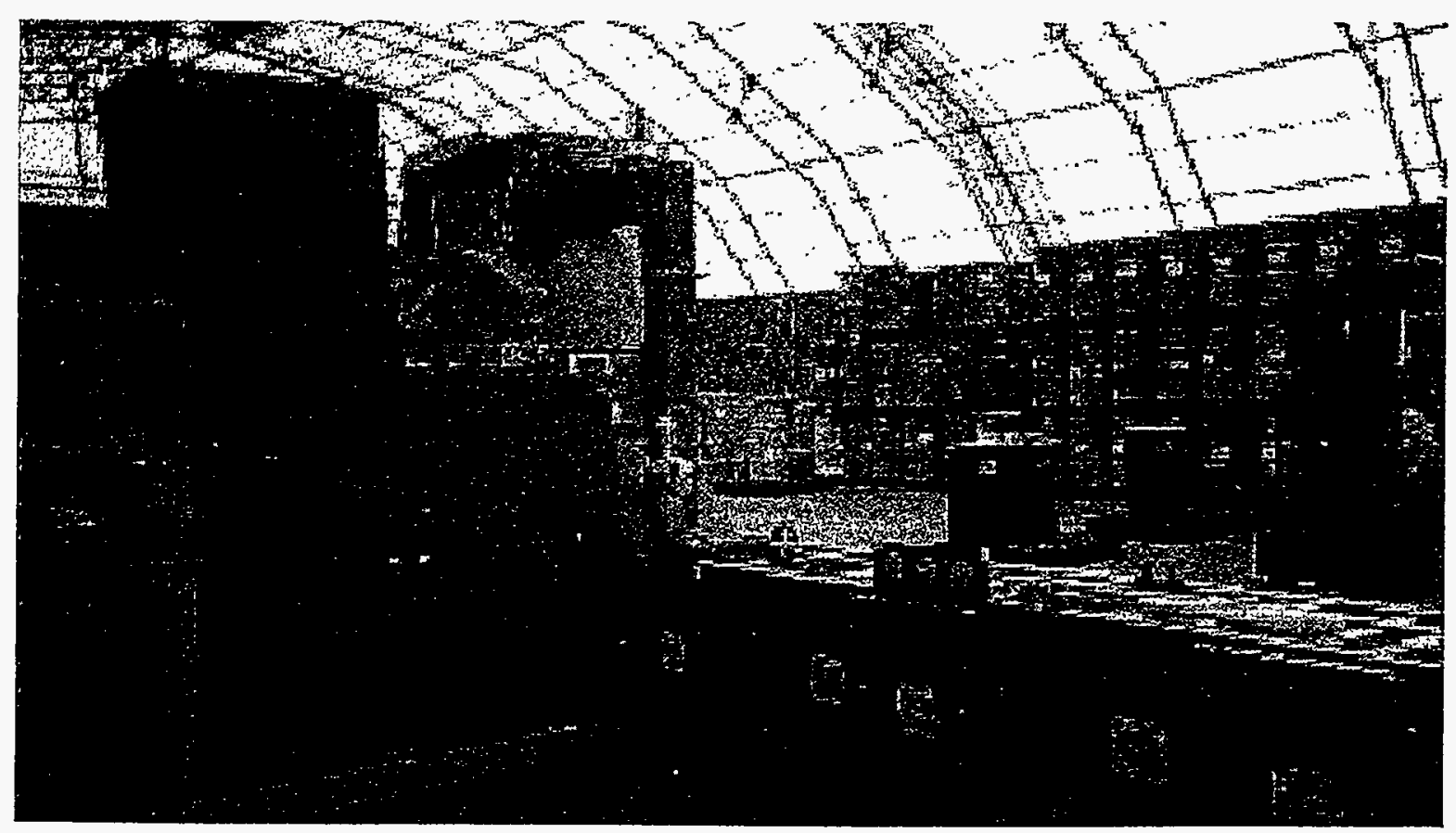

Photograph Courtesy of NFT Inc.

Figure $4.2 b$

Portable Drum Venting and Headspace Gas Sampling and Analysis System at Savannah River 


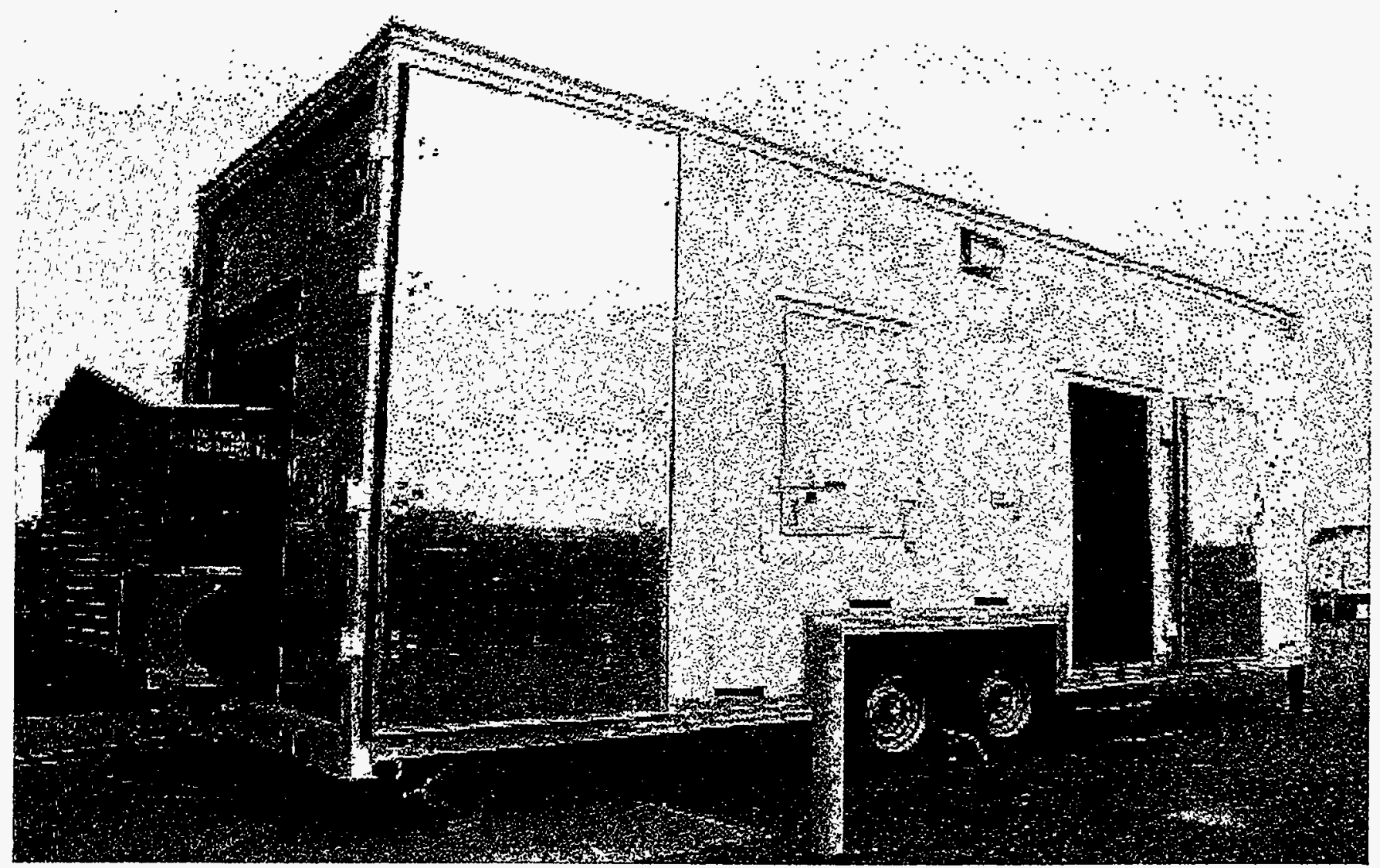

Photograph Courtesy of Los Alamos National Laboratory

Trailer Containing the Segmented/Tomographic Gamma Scanner

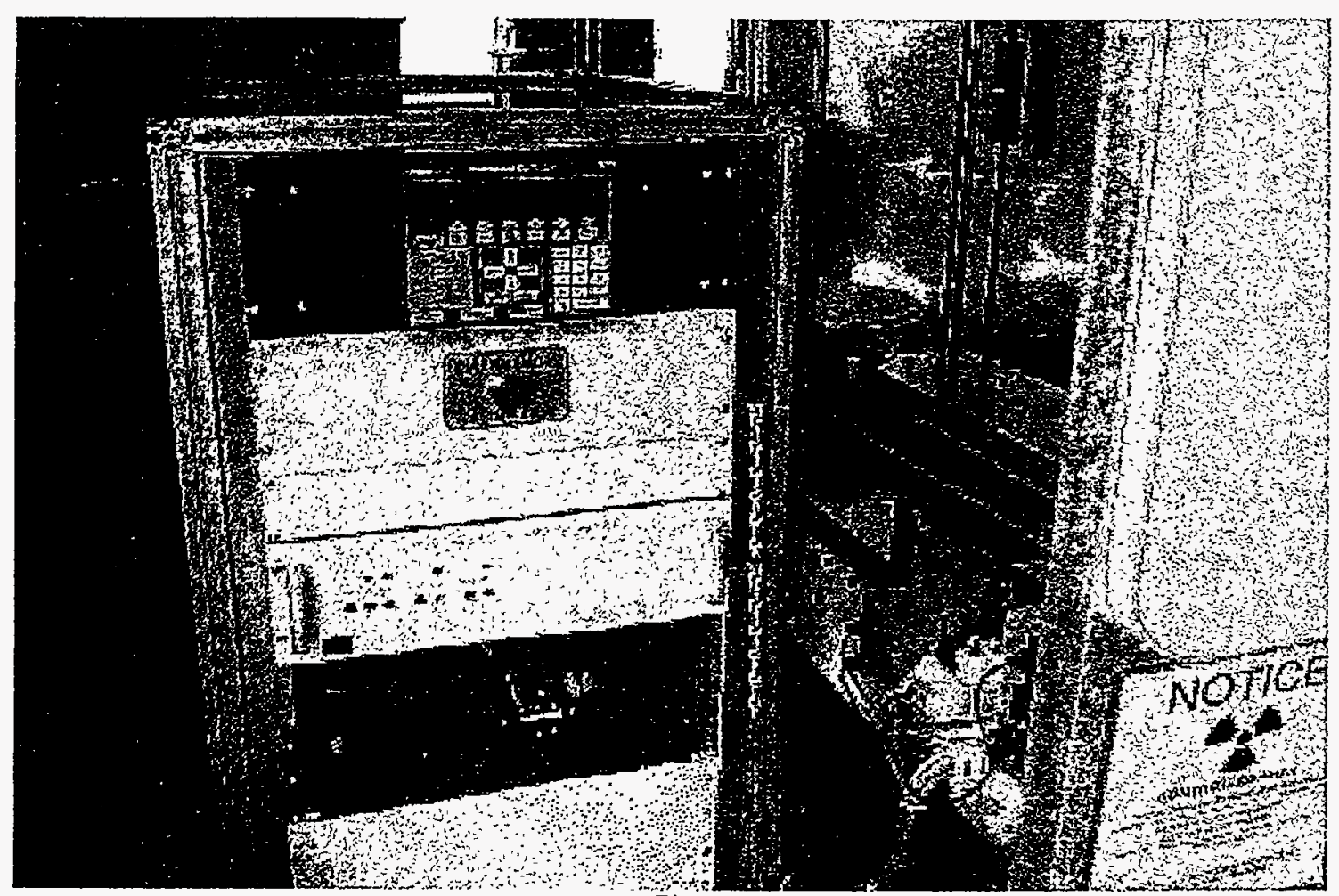

Photograph Courtesy of Los Alamos National Laboratory

The Segmented/Tomographic Gamma Scanner 


\section{PLANNING ASSUMPTIONS, SCOPE, AND METHODS}

This plan provides information needed to advance the mobile system initiative: it offers detailed information on sites' needs for mobile system services, the requirements mobile systems must meet, and the nature and availability of mobile capabilities; and it identifies steps all parties can take toward matching site needs with vendor capabilities.

As sites' planning for deployment of mobile systems progresses and sites' experience with them grows, the Carlsbad Area Office's approach will continue to evolve. Future assessments of sites' needs will broaden to encompass other TRU-waste issues that can be effectively addressed with mobile systems. How DOE sites can share the mobile capabilities they have developed with each other will continue to be examined.

\section{Sources of mobile systems}

While this plan discusses mobile system capabilities developed at DOE sites, those DOE systems are in use and generally not available to be shared, or they are one-of-a-kind prototypes and therefore limited in number. Therefore the pian focuses on the capabilities that can be provided by commercial vendors.

\section{Planning horizon}

Site needs were examined for mobile systems from Fiscal Year 1997 through the end of WIPP's expected operational lifetime in Fiscal Year 2033, because the need for mobile systems will extend well into the future, not only for TRU wastes but for other wastes.

In support of the DOE Environmental Management 10-Year Plan, which calls for disposal of most contacthandled TRU waste by the end of Fiscal Year 2006, this plan focuses on sites' needs for mobile systems from Fiscal Year 1997 through Fiscal Year 2006.

\section{Kinds of waste encompassed by this plan}

This plan covers contact-handled TRU waste only. Of contact-handled TRU wastes, this plan focuses primarily on those wastes stored in 55-gallon drums and standard waste boxes designed for TRUPACT- $I$, because waste in these drums and standard waste boxes can be characterized for certification and loaded for shipment now. Mobile systems will also be valuable for processing newly generated TRU waste.

\section{Plan preparation}

The preparation approach to this plan was comprehensive. A National TRU Program information clearinghouse was established to gather information on mobile system capabilities and site needs (contact for the clearinghouse is identified in Chapter 14). And this information enabled the following:

- review of prior mobile systems studies; 
- identification of Carlsbad Area Office and DOE sites' requirements that mobile system operations must meet;

- an assessment of sites' needs for mobile systems based on the National Transuranic Waste Management Plan;

- a survey of vendors and DOE sites to determine their mobile capabilities and the status of those capabilities (conceptual design, prototype, ready to deploy), throughput rate, and costs (acquisition, operation, and maintenance);

- discussions with vendors and custodians of DOE mobile systems to learn about their technology development demonstration programs;

- preparation of preliminary estimates of the costs of deploying mobile systems over a 10year period and assessing construction, equipment, operating, and maintenance costs for a generic fixed facility for comparative purposes;

- identification of deployment benefits at each site over a 10-year period;

- examination of mobile system acquisition strategies, including purchase, lease, and opportunities for privatization as defined by the Privatization Guidance issued by the Office of Environmental Management. 
DOE/NTP-96-1202, Rev.0

\section{BACKGROUND ON DOE'S INVESTIGATIONS OF MOBILE SYSTEMS}

Over the past decade DOE has explored the use of mobile systems, and it has found that mobile systems are the equal of fixed site installations in characterizing TRU waste to meet WIPP waste acceptance criteria. (Mobile systems have also been proven suitable for characterizing and treating mixed low-level waste to meet the requirements of the Federal Facility Compliance Act.)

- Los Alamos National Laboratory developed and field-tested mobile NDA and NDE systems. ${ }^{8}$ The field tests were conducted at Los Alamos National Laboratory and at the Nevada Test Site from July 1985 through January 1986. The several months of realistic testing, including actual assay and radiographic measurements of 1,500 drums of TRU waste, demonstrated conclusively that both mobile NDA and NDE modules are suitable for field use.

- The DOE Albuquerque Operations Office prepared the Mixed Waste Treatment Plan in March 1994 in response to the Federal Facility Compliance Act of 1992, which requires DOE to specify its plans for treating mixed waste. The plan called for commercial treatment, treatability studies, and mobile treatment units to treat approximately 7,000 drums of low-level mixed waste stored at nine DOE sites. The sites were to fund the development of their own mobile treatment capacity, which would then be shared with other sites in a demonstration of the feasibility of applying mobile treatment to mixed waste.

To help develop and use mobile treatment units, working groups were established to identify and resolve issues concerning design and operation as they affected regulatory compliance. The initial working groups addressed the following issues: mobile treatment, public participation, National Environmental Policy Act (NEPA) compliance issues, safety analyses, permitting, and waste disposal. Their final recommendations were completed on June 2, 1995.

Under this plan the Los Alamos National Laboratory has successfully field-demonstrated a waste-sorting, radiation-survey, and decontamination trailer for low-level mixed waste at the DOE Inhalation Toxicology Research Institute and the DOE Grand Junction, Colorado, facility.

- Rocky Flats Environmental Technology Site, the Savannah River Site, and Los Alamos National Laboratory, at the request of DOE's Office of Transition and Management (DOE/EM-60), studied the feasibility of using portable modular systems to stabilize plutonium residues. ${ }^{10}$ Three options were compared: 1) the stand-alone concept, 2) enclosure in a simple building, and 3) skid-mounting gloveboxes for installation in an existing building. Cost estimates were prepared for these three options. The study showed

\footnotetext{
${ }^{8}$ Mobile Nondestructive Assay and Examination Instruments, J. M. Bieri and J.T. Caldwell, LA-UR-86-2189, 1986.

${ }^{9}$ Mixed Waste Treatment Plan, DOE Albuquerque Operations Office, 1994.

${ }^{10}$ Final Report: Feasibility Study on the Modular Treatment System for Plutonium Residue Stabilization, Los Alamos National Laboratory, LA-CP-95-296, 1996.
} 
that actinide residues could be handled in portable modular systems, that these systems offer a way to stabilize actinide residues so that sites don't need to build new facilities or restart existing facilities, and that they permit reuse of equipment at more than one site. While the stand-alone concept proved feasible, the study recommended a skid-mounted modular system in an existing building because there was no pressing need for a complete portable system. The stand-alone and skid-mounted systems were shown to be cheaper than the traditional approach to stabilizing actinide residues in a fixed facility.

\section{Mobile Waste Characterization Systems Analysis Report}

Because of the promise shown by these investigations, the Carlsbad Area Office prepared the Mobile Waste Characterization Systems Analysis Report. ${ }^{11}$ It examines the use of mobile systems to characterize contact-handled retrievably stored and newly generated waste. Thirteen mobile systems were analyzed against these parameters: performance, throughput rate, cost, set-up time, and portability (weight and volume).

This report found that,

...mobile waste characterization systems have immediate application in regard to assisting the large quantity sites in filling the pipeline to the WIPP. In the long term, as more fixed waste characterization facilities come on line, services provided to the large sites by the mobile systems will be transitioned to the small quantity sites in order to assist in the consolidation of TRU waste across the DOE complex.

The report concluded that there is a need for mobile systems at DOE sites, that their use could produce significant cost savings, and that they could be rapidly deployed.

${ }^{11}$ Mobile Waste Characterization Systems Analysis Report, DOE-Carlsbad Area Office, NTP-WID-96-2163, 1996. 


\section{REQUIREMENTS, NEEDS, AND CAPABMITIES}




\section{CARLSBAD AREA OFFICE REOUIREMENTS}

The Carlsbad Area Office has established a set of requirements that sites must meet before they are authorized to certify TRU waste for disposal. Mobile systems are subject to the same requirements as fixed facilities. Those requirements are specified in several related documents and programs that have evolved as understanding of the nature of wastes and of appropriate disposal requirements has grown. These requirements are applicable to mobile systems whether they are provided by vendors or are DOE-owned.

\section{Carlsbad Area Office Quality Assurance Program}

The Carlsbad Area Office has issued the Quality Assurance Program Document ${ }^{12}$ to govern all programs and projects that it manages. The quality assurance elements of the documents listed below are derived from the Quality Assurance Program Document.

\section{Waste acceptance criteria for WIPP}

The Carlsbad Area Office specified waste acceptance criteria for WIPP in the Waste Acceptance Criteria for the Waste Isolation Pilot Plant. This document serves as the primary directive for assuring the safe handling, transportation, and disposal of TRU wastes. Sites must certify that their TRU waste meets these criteria and requirements before they ship it to WIPP for disposal.

\section{Waste characterization requirements, methods, and guidance}

The Carlsbad Area Office specified WIPP waste characterization requirements in the TRU Waste Characterization Quality Assurance Program Plan (QAPP). The QAPP establishes the data quality objectives that data produced by characterization of TRU waste must meet. These objectives specify methods of characterizing waste, acceptable levels of uncertainty, and required documentation and records management. The QAPP also specifies the performance-based quality control requirements that each mobile system participating in the TRU waste characterization program must meet.

The Transuranic Waste Characterization Sampling and Analysis Methods Manual (Methods Manual) ${ }^{13}$ explains the testing, sampling, and analytical methods that sites and vendors must use to comply with the requirements of the QAPP and the WIPP Waste Analysis Plan, which is part of the WIPP RCRA Part B Permit Application.

The DOE Waste Treatability Group Guidance provides a system for grouping wastes with similar physical and chemical properties according to matrix parameter categories. Sampling and analytical requirements described in the QAPP are based on the summary category by which the waste stream is identified (that is, homogeneous solids, soil/gravel, or debris wastes).

\footnotetext{
${ }^{12}$ Quality Assurance Program Document, Revision 1, CAO-94-1012, 1996.

${ }^{13}$ Transuranic Waste Characterization Sampling and Analysis Methods Manual, Revision 1.0, DOE/WIPP-91-043, 1996.
} 
If a vendor has an innovative technology that uses a testing, sampling, or analytical methodology not covered in the Methods Manual, the manual can be modified. The vendor should contact the Carlsbad Area Office, Manager - Waste Characterization, for assistance in obtaining such modifications.

\section{Meeting QAPP requirements for characterizing TRU waste}

Before mobile systems can be used to characterize waste on a site, the commercial vendor or the custodian of a DOE-owned mobile system must meet the applicable requirements of the QAPP. A custodian of a DOE-owned mobile system is the site where the system was acquired or developed and tested. Documentation that DOE-owned mobile systems meet the quality assurance objectives of the QAPP is included in the custodial site's Quality Assurance Project Plan. Vendors must prepare a vendor quality assurance document, which accomplishes the same purpose as a site's Quality Assurance Project Plan. The vendor quality assurance document must be approved by the Carlsbad Area Office. Once the vendors' quality assurance document is approved, a vendor may operate its mobile systems.

\section{The Performance Demonstration Program for characterizing TRU waste}

The QAPP requires those mobile systems performing NDA, headspace gas analysis, and RCRA analysis to meet quality assurance objectives. To demonstrate conformance, vendors and custodians of these systems must participate in a Performance Demonstration Program. This program provides an objective measure of the reliability of measurements performed by TRU waste characterization systems. The Carisbad Area Office uses the test results to approve measurement facilities supplying services for characterization of TRU waste.

Each testing and analytical facility performing TRU waste characterization by NDA, headspace gas analysis, and RCRA constituent analysis of solidified wastes must participate in the program by accurately testing blind audit samples twice a year. Mobile systems for headspace gas and RCRA analysis do not have to be physically present at a site to participate in a Performance Demonstration Program cycle. NDA systems must be physically present because of safeguard and security constraints associated with the test standards.

The Performance Demonstration Program is described in the following documents:

- Performance Demonstration Program Plan for Nondestructive Assay for the TRU Waste Characterization Program, DOE/CAO-94-1045, Revision 0, March 1995.

- Performance Demonstration Program Plan for the Analysis of Simulated Headspace Gases for the TRU Waste Characterization Program, DOE/CAO-95-1076, Revision 0, June 1995.

- Performance Demonstration Program Plan for RCRA Constituent Analysis of Solidified Wastes, DOE/CAO-95-1077, Revision 1, March 1996.

The Carlsbad Area Office Waste Characterization Manager administers the Performance Demonstration Program. The coordinator for the Performance Demonstration Program for both RCRA analysis and NDA is Lockheed/Martin Idaho Technologies Company at Idaho National Engineering Laboratory. The coordinator for the Performance Demonstration Program for headspace gas analysis is the Carlsbad Area 
-suoppesado

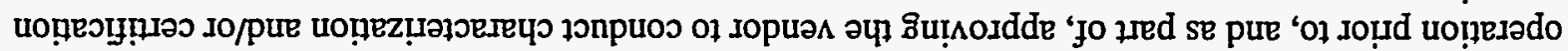
سəıs

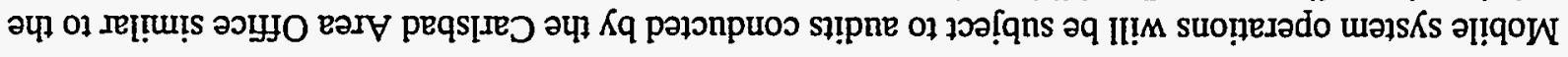

słpnץ

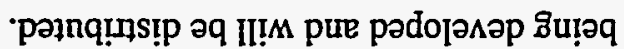

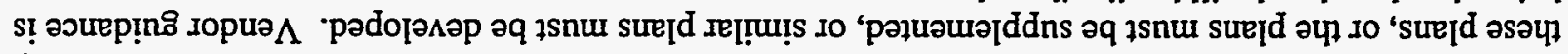

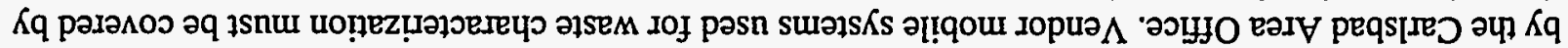

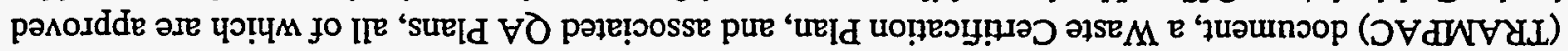

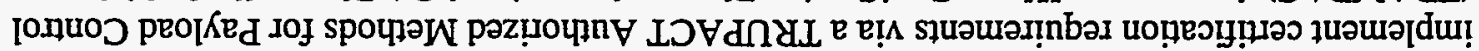

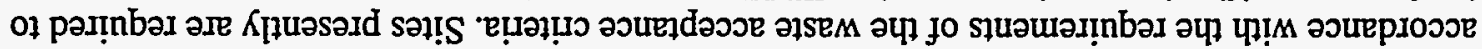

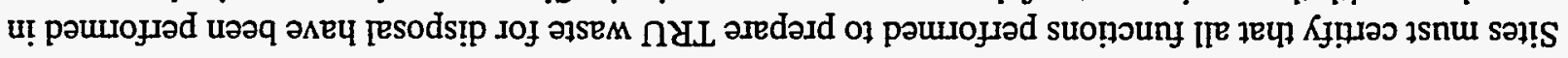

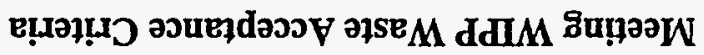

\begin{tabular}{|c|c|c|}
\hline & 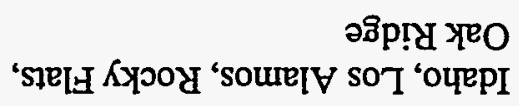 & 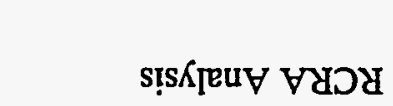 \\
\hline 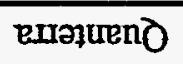 & 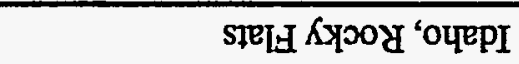 & 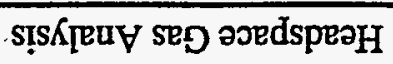 \\
\hline & 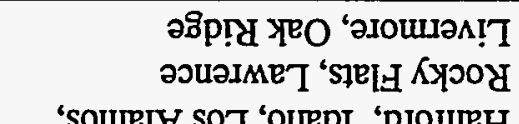 & \\
\hline & 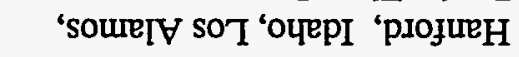 & $\mathrm{VaN}$ \\
\hline
\end{tabular}

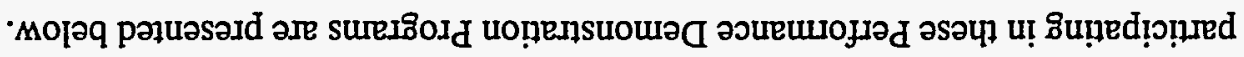

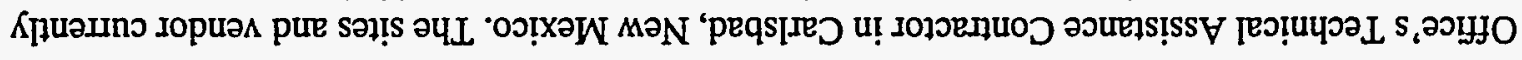

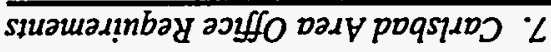




\section{THE SITE REQUIREMENTS THAT MOBILE SYSTEMS MUST MEET}

In managing TRU waste, DOE sites must comply with DOE Orders and policies and Federal, State, and local regulations in the areas of health, safety, quality assurance, safeguards, security, and environment. Mobile systems must comply with these same requirements in order to operate at a site.

For the most part, sites have formulated their requirements to apply to fixed facilities. To deploy mobile systems, vendors will want to understand the intent and nature of site requirements and work closely with individual sites to establish an operating basis that meets requirements in the most efficient way.

The Mobile Waste Characterization Systems Analysis Report, issued in January 1996, identified the DOE requirements applicable to the design and operation of a fixed facility at Los Alamos National Laboratory, and it compared them with requirements for the two types of mobile system technologies: invasive and noninvasive. The report shows that requirements for both types of mobile systems are fewer than those for fixed facilities.

\section{Site Authorization for Operation}

Before sites can incorporate any equipment or service into their operations, they must authorize its use. That authorization in effect certifies that the equipment or service will operate in full compliance with all applicable requirements. To grant this authorization, sites need supporting documentation of the health and safety-related features of the equipment. While the authorization requirements have been well-defined for fixed TRU-waste facilities, they have not yet been well-defined for mobile systems. Moreover, each site's requirements are different.

Site authorization encompasses those aspects of the facility design basis and operational requirements important to the safety of the public, the health and safety of facility workers, and protection of the environment. The authorization basis is defined in $\$ 6 \mathrm{~b}$ of DOE Order 5480.21, Unreviewed Safety Questions, as follows:

Those aspects of the facility design basis and operational requirements relied upon by DOE to authorize the operation of a facility. These aspects are considered to be important to the safety of facility operations. The authorization basis is described in documents such as the facility Safety Analysis Report and other safety analyses; Hazard Classification Documents, the Technical Safety Requirements, DOE-issued safety evaluation reports, and facility-specific commitments made in order to comply with DOE Orders or policies.

The definitional terms such as design basis, important to safety, nuclear facility, safety analysis, safety analysis report, and technical safety requirements are defined, respectively, in $\S 6 \mathrm{c}, \S 6 \mathrm{f}, \S 6 \mathrm{j}, \S 60, \S 6 \mathrm{p}$, and $\S 6 q$ of DOE Order 5480.21 .

Elements of a site authorization for a fixed facility include:

- facility and process descriptions that include any features that prevent or mitigate consequences of accidents or event scenarios below the DOE risk guidelines for the public and for facility workers; 
- hazards analysis using a detailed identification of hazards and a qualitative or semiquantitative analysis of potential scenarios, frequencies, and consequences, along with a matrix that identifies mitigating measures for each risk;

- Safety Analysis Report for a nuclear facility according to DOE Order 5480.23;

- technical safety requirements and operational safety requirements;

- NEPA documentation, such as an environmental impact statement, environmental assessments, and Appendix B Categorical Exclusion from the NEPA process (Subpart D, Appendix B classifications in 10 CFR 1021); and

- worker/institutional safety programs, such as radiation protection, industrial safety, industrial hygiene, configuration control, unreviewed safety question determination or Environmental, Safety and Health questionnaire, quality assurance, conduct of operations, maintenance program, and Environment, Safety and Health design review.

The above discussion of the elements of a site authorization was adopted from Los Alamos's Feasibility Study on the Modular Treatment System for Plutonium Residues Stabilization.

DOE and its contractors have made several efforts to define and adapt the site authorization process for mobile systems. As described above, under "Background on DOE's Investigation of Mobile Systems," the DOE Albuquerque Operations Office formed working groups to address these issues. Their recommendations are included in two documents published as a part of the site's Mixed Waste Treatment Plan. The documents also include safety basis documentation policy and guidance for the preparation of mixed waste treatment process hazards analysis.

In another effort, the Rocky Flats Environmental Technology Site has authorized vendor operation for demonstrating a mobile NDE system. Its intention was to define and standardize requirements for mobile system operation and to expedite the approval process. The NDE vendor that conducted the demonstration at the Rocky Flats site provided the following documentation to the site:

- $\quad$ its corporate Quality Manual;

- the Safety Analysis Document for the specific equipment being demonstrated, which covers a description of the facility, operations and schedule, operating safety procedures, operating safety requirements, radiological safety, Material Safety Data Sheets, and safety analysis;

- a determination by the DOE Morgantown Energy Technology Center that an Appendix B Categorical Exclusion (CX-B) is the appropriate level of NEPA documentation for the demonstration;

- a description of the operator training program and documentation of operator training;

- a copy of the radioactive materials license;

- a description of the data quality objectives for the demonstration; 
- the operations manual for the mobile equipment; and

- a sealed-source leak test analysis report on the mobile equipment prepared by Radiation Services, Inc.

On the basis of this documentation, the site approved operation of the mobile NDE system. The same vendor later submitted the same documentation to the Idaho National Engineering Laboratory and obtained approval.

\section{Other precedents for authorization}

The Idaho National Engineering Laboratory and Los Alamos National Laboratory have developed test plans for demonstrating commercial NDE and/or NDA capabilities. Their plans define required documentation and specify the documentation review and approval process for authorizing mobile system operation.

\section{Other site issues}

When sites were surveyed, site representatives were asked what requirements mobile systems would have to meet in order to operate at the sites. The data gathered covered the following subjects: availability of space and utilities; environmental permitting; safeguards and security; secondary waste handling; and safety, site transportation, training, and $\mathrm{QA}$ requirements.

Among the site issues reported were the following:

- Labor issues. At some sites, local labor issues may influence whether vendor personnel or site personnel operate the mobile equipment. The DOE sites are operated by contractor organizations that enter into agreements with subcontractors and unions to perform defined tasks, and sites usually employ both union and nonunion workers. Each site must resolve the issue of who will operate the mobile system before the system can be implemented.

- Planning. Before they implement mobile systems, sites must plan the flow of waste to minimize downtime as containers of waste are moved to or away from the mobile system.

- Training. Health and safety training and training in site security procedures will be required for vendor personnel operating equipment. If site personnel are to operate the equipment, sites must designate operators and arrange training with the mobile system vendor. 


\section{SITES' NEEDS FOR MOBILE SYSTEMS}

Presently, there is 102,000 cubic meters of retrievably stored, contact-handled TRU waste stored at numerous sites around the country. More than 99 percent of this waste is stored at Hanford, Idaho National Engineering Laboratory, Lawrence Livermore National Laboratory, Los Alamos National Laboratory, the Nevada Test Site, Oak Ridge National Laboratory, the Rocky Flats Environmental Technology Site, the Savannah River Site, Argonne National Laboratory-East, and the Mound Plant.

While these 10 sites store more than 99 percent of TRU waste inventories, the small-quantity sites, with less than 1 percent of total inventories, represent far more than 1 percent of the costs and responsibilities associated with managing TRU waste. Consequently, mobile systems are of particular value for them.

This chapter identifies how mobile capabilities might be used at DOE sites. Site needs were examined through Fiscal Year 2033, with a focus on the 10 years from Fiscal Year 1997 through Fiscal Year 2006. To understand how sites might best use mobile system capabilities, the following information was sought for each site: 1) the volume of contact-handled TRU waste it must prepare for shipment, 2) its existing and planned capabilities for preparing that inventory, and 3) its work-off schedule. The DOE complex is a large, complex working environment in which data, planning assumptions, and forecasts are subject to change and in which documents are often overtaken by change. In identifying current site capabilities, site needs, and site plans for meeting their needs, information from the National Transuranic Waste Management Plan was used as the primary basis.

\section{Sources of information}

Information about sites' waste inventories came from two primary sources: the National Transuranic Waste Management Plan, September 1996, and the Contact-Handled Transuranic Waste Characterization Systems Analysis, September 1995. In summary, these documents offer the following information:

- National Transuranic Waste Management Plan. Data packages prepared by the large TRU waste sites were used to develop this plan. The data packages identify sites' existing inventories of TRU waste and the quantities of TRU waste they plan to ship to WIPP each year. They also describe each site's capabilities to prepare TRU waste for shipment. Using throughput capacities for each stage of TRU waste management operations, process flow diagrams were developed that illustrate, over time, site-specific TRU waste operations for certifying waste for shipment to WIPP. These process flow diagrams show what fixed facilities exist or are planned for TRU waste preparation. Using this information and the throughput capacities, waste types, and volume information in the data packages, mobile system needs were identified.

- The Contact-Handled Transuranic Waste Characterization System Analysis provides a technical basis for characterizing contact-handled TRU waste. This analysis also identifies contact-handled TRU waste inventories and existing waste characterization facilities. 
Sites' existing and planned facilities

Most sites have facilities, or are planning to build fixed facilities, to characterize, repackage, and treat TRU waste and to load it into TRUPACT-II containers-for shipment. Some sites, including small-quantity sites, do not plan to build new facilities; instead, they plan to use mobile systems. Table 9.1 presents information on sites' existing fixed and mobile facilities and planned fixed facilities. Blank cells in this table indicate that no facilities exist or are planned for that function.

Table 9.1 - TRU Waste Processing Capabilities: Fixed Facilities (Existing and Planned) and Existing Mobile Systems by DOE Site

\begin{tabular}{|c|c|c|c|c|c|c|c|c|}
\hline \multirow[t]{2}{*}{ DOE Site } & $=\cdots$ & $\therefore$ & Characteri & ion & $\because$ & \multirow{2}{*}{$\begin{array}{c}\text { Repack- } \\
\text { aging } \\
y \\
0 \\
0\end{array}$} & \multirow{2}{*}{$\begin{array}{l}\text { Treatment } \\
\therefore \\
\therefore\end{array}$} & \multirow{2}{*}{$\begin{array}{c}\text { TRUPACT- } \\
\mathbf{n} \\
\text { Loading } \\
\vdots \\
\vdots\end{array}$} \\
\hline & $\begin{array}{r}\text { NDE } \\
4 \\
\end{array}$ & \begin{tabular}{r}
$\mathbf{N D A}$ \\
0 \\
\hdashline \\
\hdashline \\
\end{tabular} & $\begin{array}{l}\text { Visual } \\
\text { Exama } \\
\end{array}$ & $\begin{array}{l}\text { Headspace } \\
\text { Gas. } \\
\text { Sampling } \\
\text { Analysis }\end{array}$ & $\begin{array}{l}\text { RCRA } \\
\text { Sampling } \\
\text { (coring) }\end{array}$ & & & \\
\hline Hanford & $\mathrm{X}$ & $X$ & $x$ & $\mathrm{X}$ & $\mathrm{X}$ & $\begin{array}{l}X, P \\
(2005)\end{array}$ & & $\mathrm{X}$ \\
\hline Idaho & $\mathrm{X}$ & $\mathrm{x}$ & $" \mathrm{X}^{\prime}$ & $\mathrm{x}$ & $\mathrm{x}$ & $\begin{array}{c}\mathrm{P} \\
(2003)\end{array}$ & $\begin{array}{c}\mathrm{P}^{\prime} \\
(2003)\end{array}$ & $\begin{array}{c}X, P \\
(2003)\end{array}$ \\
\hline Los Alamos & $\mathrm{M}, \mathrm{X}$ & $\mathrm{M}, \mathrm{X}$ & $\mathrm{x}$ & $\mathrm{M}, \mathrm{X}$ & $\mathrm{x}$ & $\mathrm{x}$ & & $\mathrm{X}$ \\
\hline Rocky Flats & $\mathrm{X}$ & $\mathrm{X}$ & $\mathrm{X}$ & $\mathrm{x}$ & $\mathrm{x}$ & $\mathrm{X}$ & & $\mathrm{x}$ \\
\hline Savannah River & $\begin{array}{c}P \\
(2008)\end{array}$ & $\begin{array}{c}P \\
(2008)\end{array}$ & $\underset{(2008)}{P}$ & & $\underset{(2008)}{P}$ & $\begin{array}{c}P \\
(2008)\end{array}$ & & \\
\hline $\begin{array}{l}\text { Lawrence } \\
\text { Livermore }\end{array}$ & $\mathbf{M}$ & $\begin{array}{c}X, P \\
(1998)\end{array}$ & $\mathrm{X}$ & $\mathbf{M}$ & $\begin{array}{c}P \\
(1998)\end{array}$ & $\begin{array}{c}P \\
(2000)\end{array}$ & & $\begin{array}{c}P \\
(1999)\end{array}$ \\
\hline Nevada Test Site & $\underset{(1998)}{P}$ & $\begin{array}{c}\mathrm{P} \\
(1998)\end{array}$ & $\begin{array}{c}\mathrm{P} \\
(1998)\end{array}$ & $\begin{array}{c}P \\
(1998)\end{array}$ & & $\begin{array}{c}P \\
(1998)\end{array}$ & & \\
\hline Oak Ridge & $\begin{array}{c}X, P \\
(2002)\end{array}$ & $\begin{array}{c}X, P \\
(2002)\end{array}$ & $\underset{(2002)}{P}$ & & & $\underset{(2002)}{P}$ & & \\
\hline \multicolumn{9}{|l|}{ Argonne-East } \\
\hline Mound Plant & & & & & & $\begin{array}{c}\mathrm{X}, \mathrm{P} \\
\text { (1999) }\end{array}$ & & \\
\hline $\begin{array}{l}\text { Small-Quantity } \\
\text { Sites }\end{array}$ & & & & & & & & \\
\hline
\end{tabular}

Legend: $X$ represents fixed capability: existing

$P$ represents fixed facility: planned; start date is in parentheses

$M$ represents existing capability: mobile 
Table 9.2 identifies sites' plans for using mobile systems to prepare TRU waste for shipment. The table does not include a column for treatment, as no site indicated a need for mobile treatment services. The dates in this table reflect the TRU waste work-off schedules for the sites presented in the National Transuranic Waste Management Plan (Management Plan), as well as sites' schedules for using existing and planned facilities.

The capabilities of small-quantity sites are considered as the equivalent of a single facility in the Management Plan configuration model of sites' TRU waste work-off schedules; they are presented similarly in Tables 9.2 and 9.3.

A brief description of needs for mobile systems at each of the 10 large sites and at the small-quantity sites follows:

\section{Hanford}

Hanford is planning to build a new waste management facility called WRAP I. When it becomes operational in 1998, NDE, NDA, headspace gas sampling and analysis, repackaging, RCRA sampling, and TRUPACT-II loading will be performed in it.

\section{Idaho National Engineering Laboratory}

Currently NDE and NDA are performed at the Stored Waste Examination Pilot Plant; Argonne National Laboratory-West is performing visual examination, RCRA sampling (coring), and headspace gas sampling and analysis on Idaho's waste. The site plans to build an Advanced Mixed Waste Treatment Facility to treat and characterize TRU waste. The facility is scheduled to open in April 2003.

Two mobile TRUPACT-II loading units will be needed to support the scheduled shipments.

\section{Los Alamos National Laboratory}

Los Alamos has developed a mobile capability to supplement its fixed facilities for characterizing TRU waste. It is retrieving and characterizing its waste to comply with a compliance order issued by the New Mexico Environment Department, as well as with WIPP's certification requirements.

The only capability Los Alamos needs are headspace gas analysis and possibly additional gloveboxes to open, visually examine, and repackage waste. Two portable gloveboxes are being constructed for RCRA coring and sampling and for a visual exam, but more may be needed. This mobile capability will be used for all TRU waste stored at Los Alamos until work-off is complete (Fiscal Year 2006).

Argonne-East, Mound Plant, and the small-quantity sites will ship a statistical sampling of TRU waste containers to Los Alamos for coring and visual exam services. 
Table 9.2 - Potential Use of Additional Mobile Systems Based on Site Needs

\begin{tabular}{|c|c|c|c|c|c|c|c|c|c|}
\hline \multirow{2}{*}{$\begin{array}{l}\text { DOE Site } \\
\because \because ;\end{array}$} & \multicolumn{2}{|r|}{ 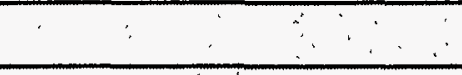 } & \multicolumn{2}{|c|}{ Characterization } & \multirow{2}{*}{\multicolumn{4}{|c|}{ 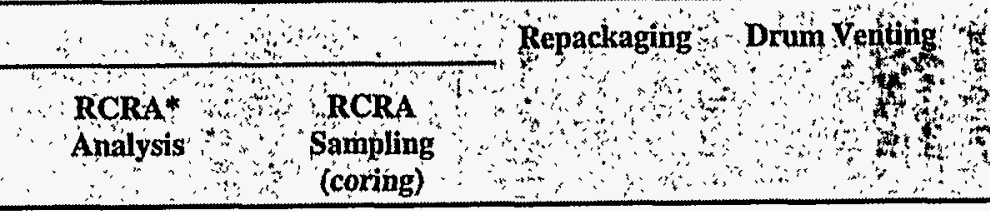 }} & \multirow{2}{*}{ Trupugan } \\
\hline & $\because$ NDE & $\because \begin{array}{c}\ddots \mathbf{N D A} \\
\because \\
\end{array}$ & \begin{tabular}{c} 
Vișual Exam \\
\hdashline \\
\end{tabular} & $\begin{array}{l}\text { Headspace Gas } \\
\text { Sampling \& } \\
\text { Analysis }\end{array}$ & & & & & \\
\hline \multicolumn{10}{|l|}{ Hanford } \\
\hline Idaho & & & & & & & $\because$ & $\therefore \therefore$. & $2003-2033$ \\
\hline Los Alamos & & & $\begin{array}{c}* * 1998-2033 \\
\text { supplement }\end{array}$ & & $\begin{array}{c}* * 1998-2033 \\
\text { supplement }\end{array}$ & $\begin{array}{c}* * 1998-2033 \\
\text { supplement }\end{array}$ & & & \\
\hline Rocky Flats & & & & & & & 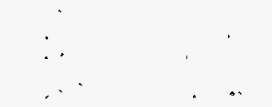 & \begin{tabular}{l}
$\vdots$ \\
$\because$ \\
\hdashline \\
\hdashline
\end{tabular} & $\begin{array}{l}1998-2006 \\
\text { supplement }\end{array}$ \\
\hline $\begin{array}{l}\text { Savannah } \\
\text { River }\end{array}$ & $1998-2010$ & $1998-2010$ & & $1998-2010$ & & & & & $1998-2033$ \\
\hline $\begin{array}{l}\text { Lawrence } \\
\text { Livermore }\end{array}$ & & $1998-2033$ & & & & $\begin{array}{c}1998-2033 \\
\ldots\end{array}$ & $\begin{array}{c}\because \\
\because \because \cdots \\
\because \cdots\end{array}$ & 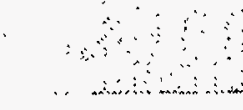 & 19982033 \\
\hline $\begin{array}{l}\text { Nevada } \\
\text { Test Site }\end{array}$ & & & & & & & & & $1999-2002$ \\
\hline Oak Ridge & & & & $1998-2001$ & . & & $\begin{array}{l}\cdot \cdots \\
\because \because \\
\because\end{array}$ & $\because \vdots \vdots \begin{array}{l}\cdots \\
\because \\
\vdots\end{array}$ & $\begin{array}{l}1998-2001 \text { and } \\
2002-2022\end{array}$ \\
\hline Argonne-East & $\begin{array}{c}2002-2006 \text { and } \\
2020-2033\end{array}$ & $\begin{array}{c}2002-2006 \text { and } \\
2020-2033\end{array}$ & & $\begin{array}{c}2002-2006 \text { and } \\
2020-2033\end{array}$ & & & & & $\begin{array}{c}2003-2006 \text { and } \\
2020-2033\end{array}$ \\
\hline Mound Plant & $2002-2005$ & 2002-2005 & & $2002-2005$ & & & $\therefore$ & $\therefore \ldots$ & $2003-2005$ \\
\hline $\begin{array}{l}\text { Small- } \\
\text { Quantity Sites }\end{array}$ & $\begin{array}{c}2002-2006 \text { and } \\
2020-2033\end{array}$ & $\begin{array}{c}2002-2006 \text { and } \\
2020-2033\end{array}$ & & $\begin{array}{c}2002-2006 \text { and } \\
2020-2033\end{array}$ & & & & & $\begin{array}{c}2003-2006 \text { and } \\
2020-2033 \\
\end{array}$ \\
\hline
\end{tabular}

$Y Y-Y Y \quad$ Represents period during which mobile system is needed.

* RCRA analysis can be performed by sending samples to fixed laboratories. However, only four laboratories are participating in the PDP. It is possible that the need for RCRA analysis is greater

* than has been identified.

** Los Alamos intends to provide coring, visual exam, and analytical services to Argonne-East, Mound Plant, and small-quantity sites. This capability may be supplemented by mobile systems. 


\section{Rocky Flats Environmental Technology Site}

Rocky Flats believes it has enough fixed-facility capability to characterize TRU waste without using mobile systems. Mobile TRUPACT-II loading may be needed to supplement existing shipping facilities. If treatment is needed, waste will be sent to Idaho National Engineering Laboratory.

However, if the planned project for decommissioning is funded and proceeds, the site will need mobile capability to perform NDA, NDE, headspace gas analysis, visual examination, coring, repackaging, oxidation, immobilization, and neutralization. The site plans to either contract for these mobile capabilities as a service or lease them as dedicated units. No direct purchase is planned.

\section{Savannah River Site}

Savannah River is planning a TRU waste characterization and processing facility that will perform all necessary waste characterization and treatment beginning in 2008. Before 2008, the site plans to rely on mobile systems for coring, visual examination, and RCRA analysis. For TRUPACT-II loading, the site plans to use a dedicated mobile loading facility throughout the work-off.

\section{Lawrence Livermore National Laboratory}

Lawrence Livermore will use mobile services for NDA, RCRA coring, and TRUPACT-II loading.

\section{Nevada Test Site}

The Nevada Test Site will operate a planned Waste Examination Facility from 1998 through 2002; it will perform venting and headspace gas sampling, NDE, NDA, and visual examination. The only mobile system planned for this site is a mobile TRUPACT-II loading unit that will be used from 1999 to 2002.

\section{Oak Ridge National Laboratory}

Oak Ridge will be using the Waste Examination and Assay Facility for most of its TRU waste characterization needs; it is scheduled to begin operation in 1998 and will operate through 2001. The facility will perform NDE, NDA, and headspace gas sampling using a portable sampler. Oak Ridge also plans to construct a separate repackaging facility that will operate from 2002 through 2022, and a dedicated mobile TRUPACT-II loading facility.

\section{Argonne National Laboratory-East}

The Argonne National Laboratory-East will require mobile NDA, NDE, and headspace gas sampling and analysis capability to prepare TRU waste for shipment to WIPP. Mobile TRUPACT-II loading will also be needed between 2003 and 2006, as well as between 2020 and 2033. The site will send a statistical sampling of TRU waste containers to Los Alamos for RCRA coring and visual examination. 


\section{Mound Plant}

The Mound Plant is being shut down and cleaned up. The stored waste can be repackaged at the site, if necessary. NDA, NDE, and headspace gas sampling and analysis mobile systems will be needed. A TRUPACT-II mobile loading unit will also be needed between 2003 and 2005 . The site will send a statistical sampling of TRU waste containers to Los Alamos for RCRA coring and visual examination.

\section{Small-quantity sites}

Mobile system services will be used at all small-quantity sites to repackage their TRU waste into drums and standard waste boxes, which will then be placed in storage to await mobile assay and headspace gas sampling and analysis. The waste in drums will undergo NDE in a mobile facility and will then go to a mobile assay unit. Mobile units will be used to load the waste into TRUPACT-II shipping containers.

The National Transuranic Waste Management Plan combined 13 small-quantity sites with contacthandled TRU waste and modeled them as one entity. These sites are listed in Appendix B, which states the size of their inventories. Those sites are Ames Laboratory, ARCO Medical Products Company, Bettis Atomic Power Laboratory, Babcock \& Wilcox-Lynchburg, Energy Technology Engineering Center, General Electric - Vallecitos Nuclear Center, Lawrence Berkeley Laboratory, U.S. Army Material Command, University of Missouri Research Reactor, Paducah Gaseous Diffusion Plant, Pantex Plant, Sandia National Laboratories-Albuquerque, and Teledyne Brown.

Two other small-quantity sites, Battelle Columbus Laboratory and Knolls Atomic, are not listed in Appendix $B$ because their inventories are remote-handled waste.

\section{Summary of site needs}

Table 9.3 identifies the number of sites reporting the need for additional mobile capability from Fiscal Year 1997 through Fiscal Year 2006. The table reflects information taken from the National Transuranic Waste Management Plan: 1) the planning assumptions about TRU waste shipments to WIPP, 2) sites' existing and planned facilities, and 3) the capabilities each site will need to meet their work-off schedule for WIPP.

Note that Table 9.3 identifies only needs and the needs have not been quantified. That is, if a site identified a need for a mobile system, it was noted as one unit of measure. Needs that involve large inventories of waste may require more mobile-system capacity than needs involving smaller inventories. 
Table 9.3 - Number of Sites Needing Additional Mobile Systems:

Fiscal Years 1997 - 2006

\begin{tabular}{|c|c|c|c|c|c|c|c|c|c|c|}
\hline & 97 & 98 & 99 & 00 & 01 & 02 & 03 & 04 & 05 & 06 \\
\hline \multicolumn{11}{|l|}{ CHARACTERIZATION } \\
\hline $\mathrm{NDE}$ & & 1 & 1 & 1 & 1 & 4 & 4 & 4 & 4 & 3 \\
\hline NDA & & 2 & 2 & 2 & 2 & 5 & 5 & 5 & 5 & 3 \\
\hline Visual Exam & & 1 & 1 & 1 & 1 & 1 & 1 & 1 & 1 & 1 \\
\hline $\begin{array}{l}\text { Headspace Gas Sampling } \\
\text { and Analysis }\end{array}$ & & 2 & 2 & 2 & 2 & 4 & 4 & 4 & 4 & 3 \\
\hline $\begin{array}{l}\text { RCRA Sampling and } \\
\text { Analysis }\end{array}$ & & 2 & 2 & 2 & 2 & 2 & 2 & 2 & 2 & 2 \\
\hline \multicolumn{11}{|l|}{$\begin{array}{l}\text { REPACKAGING (no sites } \\
\text { identified mobile treatment) }\end{array}$} \\
\hline \multicolumn{11}{|l|}{$\begin{array}{l}\text { TREATMENT (no sites identified } \\
\text { mobile treatment) }\end{array}$} \\
\hline \multicolumn{11}{|l|}{$\begin{array}{l}\text { DRUM VENTING (no sites } \\
\text { identified mobile treatment) }\end{array}$} \\
\hline TRUPACT-II LOADING & & 3 & 5 & 5 & 5 & 5 & 8 & 8 & 8 & 7 \\
\hline
\end{tabular}

Note: Numbers in cells represent units of need, not of equipment; needs are not quantified.

\section{Extrapolating from information on site needs and plans}

Mobile services are clearly needed, but to calculate how many mobile systems of each type are needed, the following must be known: site work-off schedules, waste volumes, and throughput rates. Work-off schedules and waste volumes are known; throughput rates can vary significantly depending on the type of waste and equipment configuration.

Information on throughput rates comes from vendors and DOE custodians of mobile systems. Most of their information is based on vendor experience under controlled laboratory conditions; in only a few cases are data based on actual field experience. Even in the case of field demonstrations the environment is carefully controlled: that is, waste forms are known and calibration standards are used to measure equipment performance.

By contrast, field conditions vary widely. Waste forms and radionuclides are not as well known; waste containers may be damaged. Consequently, actual throughput rates may drop considerably as a result of conditions having nothing to do with equipment. Moreover, while throughput rates assume a steady flow of waste containers to and from the equipment, they will be affected by sites' ability to stage the waste for processing. 
The data we gathered from vendors include throughput data. They are presented below, but they must be verified by actual field experience to be useful, and the results could vary considerably from what is given below.

\begin{tabular}{lcccc}
\hline Capability & Throughput Rate & $\cdots$ & $\begin{array}{c}\text { Annual Rate* } \\
\text { (drums per hour) }\end{array}$ & \begin{tabular}{c} 
(2,000 hours x drums/hour) \\
\hline NDE
\end{tabular} \\
NDA & 4 & 8,000 \\
Visual exam/repackaging & 4 & 8,000 \\
Headspace gas & .4 & 750 \\
sampling/analysis & 4 & 8,000 \\
RCRA sampling & .3 & 500 \\
Drum venting & 3 & 6,000 \\
\hline
\end{tabular}

*Annual rate could be increased by adding labor shifts. 


\section{MOBILE SYSTEM CAPABILITIES: EXISTING AND UNDER DEVELOPMENT}

\section{Surveying sites and vendors}

To supplement the information in the clearinghouse, DOE sites and vendors in this country and abroad were surveyed to identify their current mobile system capabilities, and the information compiled was verified. A copy of the blank capability checklist form sent to DOE sites and U.S. and foreign vendors is in Appendix C. Copies of the completed checklists returned are available through the information clearinghouse.

For ease of reference, the information gathered is presented in tabular form at the end of this chapter. For the sake of brevity, acronyms have been used in these tables. They are included in the list of acronyms at the end of this document.

The information sought concerned the following:

- $\quad$ equipment cost (if purchased);

- what kinds of containers can be handled: 55-gallon drums and/or standard waste boxes;

- whether mobile or portable;

- throughput rate for drums and/or standard waste boxes, and whether this was based on actual field experience;

- number of personnel required to operate the equipment;

- operating costs;

- maintenance costs;

- $\quad$ set-up and break-down times for system at the site;

- $\quad$ life cycle (number of years until a system must be retired); and

- $\quad$ system status; conceptual design stage, prototype stage, or ready to go.

\section{Surveys of existing U.S. capabilities}

Table 10.1, Mobile System Capabilities of DOE Sites and U.S. Vendors, summarizes the information taken from surveys of American firms and the custodians of DOE-owned systems. The firms listed have mobile systems that are in the conceptual design stage, or are prototypes, or are field-tested and ready for deployment. The table also lists mobile capabilities for low-level waste treatment and characterization that may be modified for TRU waste, and vendors that have designed mobile equipment to characterize and treat TRU waste but are seeking a contract to build and test the equipment. The status of each mobile unit is indicated (conceptual design, prototype, or ready to deploy). 


\section{Surveys of foreign-vendor capabilities}

Names of foreign vendors were obtained from the American Nuclear Society's 1996 Nuclear News Buyers Guide. To obtain information from these vendors, survey forms were faxed to 26 of them in 11 countries. To date, 13 vendors have responded. The information they supplied is summarized in Table 10.2, Mobile System Capabilities of Foreign Vendors.

\section{Technology development demonstrations}

In this chapter, information is presented from vendors about demonstrations related to technology development efforts funded by DOE's Environmental Management technology development program (EM-50), DOE sites, and vendors.

The demonstrations funded by EM-50 were conducted by commercial vendors at Rocky Flats and will be conducted at Idaho National Engineering Laboratory. NDE technology was demonstrated on approximately 100 drums at Rocky Flats. NDE and NDA will be demonstrated on 100 drums at Idaho National Engineering Laboratory. Commercial NDA and NDE systems will also be demonstrated at Los Alamos. The drums will consist of multiple waste forms representative of TRU waste throughout the DOE complex. At the Savannah River Site, a commercial vendor demonstrated drum venting capability on 400 drums of retrievably stored TRU waste. The Carisbad Area Office has demonstrated its mobile Fourier Transform Infrared Spectrometer for headspace gas analysis on approximately 300 drums of TRU waste at the Lawrence Livermore Laboratory. 
Table 10.1 - Mobile System Capabilities of DOE Sites and U.S. Vendors

\begin{tabular}{|c|c|c|c|c|}
\hline \multirow[t]{2}{*}{ CAPABILITY } & \multicolumn{3}{|c|}{ STATUS } & \multirow[t]{2}{*}{ REMARKS } \\
\hline & $\begin{array}{l}\text { Concept- } \\
\text { ual } \\
\text { Design }\end{array}$ & $\begin{array}{l}\text { Proto- } \\
\text { type }\end{array}$ & $\begin{array}{l}\text { Ready } \\
\text { to Go }\end{array}$ & \\
\hline CHARACTERIZATION & & & & 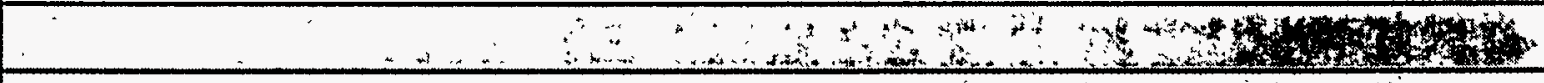 \\
\hline NDE & & & & . \\
\hline Los Alamos & & & $\mathrm{X}$ & $\begin{array}{l}\text { RTR with } 450 \mathrm{KeV} \text { x-ray sources (V. J. Technologies), linear diode array with an image intensifier. For } 55 \text {-gallon } \\
\text { drums and SWBs. Mounted on a trailer with fire suppression. Field tested with drums at Rocky Flats. SWB capability } \\
\text { not field tested yet. }\end{array}$ \\
\hline Savannah River & & $\mathrm{X}$ & & $\begin{array}{l}\text { Ten-year-old mobile RTR upgraded to an automated digital radiography inspection system; currently used to examine } \\
\text { welds on new drums. Must be modified for TRU waste NDE. The system has its own trailer and is set up for drums. }\end{array}$ \\
\hline $\begin{array}{l}\text { Advanced Technology } \\
\text { \& Engineering } \\
\text { Enterprises }\end{array}$ & $\mathrm{x}$ & & & $\begin{array}{l}\text { Personnel formerly with Diagnostics Technologies have founded a company named Advanced Technology and } \\
\text { Engineering Enterprises in Española, New Mexico. Concepts for an NDE product line are under development and } \\
\text { await funding. }\end{array}$ \\
\hline ELS, Inc. & & & $X$ & RTR (digital radiography) units mounted in trailers, one for boxes and one for drums. \\
\hline $\begin{array}{l}\text { Liberty Technologics, } \\
\text { Inc. }\end{array}$ & $\mathrm{X}$ & & & $\begin{array}{l}\text { High-resolution radiographic image acquisition system; uses no film. PC-based digital process analysis and display. } \\
\text { No application or field testing to date with TRU waste. Demonstrated mobile capability with extensive non-DOE } \\
\text { industrial application. }\end{array}$ \\
\hline $\begin{array}{l}\text { Lockheed Martin } \\
\text { Specialty } \\
\text { Components/Bio- } \\
\text { Imaging Research, } \\
\text { Inc. }\end{array}$ & & & $\mathrm{X}$ & $\begin{array}{l}\text { Waste inspection tomography, consisting of digital radiography with } 2 \mathrm{MeV} \text { sources, computed tomography, and } \\
\text { gamma scanning. Mounted on a trailer. Ready for field testing at Idaho on combustibles, sludges, and cemented waste. } \\
\text { Demonstration will be in conjunction with the active/passive neutron examination and assay, which has NDA } \\
\text { capability and is also owned by Lockheed Martin Specialty Components/Bio-Imaging Research, Inc. }\end{array}$ \\
\hline $\begin{array}{l}\text { Scientific } \\
\text { Measurements, Inc. }\end{array}$ & $\mathrm{x}$ & & & $\begin{array}{l}\text { NDE (RTR, digital radiography, and computed tomography scanners). Extensive field applications but not for TRU } \\
\text { waste. }\end{array}$ \\
\hline V. J. Technologies & & & $\mathrm{X}$ & RTR, digital radiography, and computed tomography. For boxes and drums that were field tested at Los Alamos. \\
\hline NDA & & & & \\
\hline Los Alamos & & & $X$ & $\begin{array}{l}\text { Segmented/tomographic gamma scanner for assay of low-density waste in drums. System is mounted in a trailer and } \\
\text { has been field tested at Rocky Flats. }\end{array}$ \\
\hline
\end{tabular}


Table 10.1 - Mobile System Capabilities of DOE Sites and U.S. Vendors

\begin{tabular}{|c|c|c|c|c|}
\hline \multirow[t]{2}{*}{ CAPABILITY } & \multicolumn{3}{|c|}{ STATUS } & \multirow[t]{2}{*}{ REMARKS } \\
\hline & $\begin{array}{l}\text { Concept- } \\
\text { ual } \\
\text { Design }\end{array}$ & $\begin{array}{l}\text { Proto- } \\
\text { type }\end{array}$ & $\begin{array}{l}\text { Ready } \\
\text { to Go }\end{array}$ & \\
\hline Los Alamos & & & $\mathrm{X}$ & $\begin{array}{l}\text { Passive active neutron (PAN) interrogation for drums. Ten-year-old PAN has been upgraded at Los Alamos (software } \\
\text { upgrade by Idaho). The system is mounted on an internodal DOT Type A container and is mobile and has been field } \\
\text { tested on Los Alamos waste and also at Nevada Test Site about } 10 \text { years ago. }\end{array}$ \\
\hline Canberra & & & $X$ & Passive neutron examination capability for drums. Models WM-3100 and JCC-31 are mounted on a trailer. \\
\hline Canberra & & $X$ & & Model WM-3200 shuffler is a neutron examination capability that is portable and for drums. \\
\hline Canberra & & & $X$ & $\begin{array}{l}\text { Model IQ3 is an assay system that can discriminate LLW from TRU waste in drums. The equipment is mounted on a } \\
\text { trailer. }\end{array}$ \\
\hline Canberra & & $\mathrm{X}$ & & Model WM-4100 segmented gamma and passive neutron capability is portable and for drums. \\
\hline $\begin{array}{l}\text { Lockheed Martin } \\
\text { Specialty } \\
\text { Components/Bio- } \\
\text { Imaging Research, } \\
\text { Inc. }\end{array}$ & & & $\mathrm{X}$ & $\begin{array}{l}\text { Active/passive neutron examination and assay for drums. Mounted in a trailer. Currently being field tested at Oak } \\
\text { Ridge on sludges. Will continue field testing at Idaho on combustible wastes. Commercialization and field testing by } \\
\text { agreement with Lawrence Livermore. }\end{array}$ \\
\hline $\begin{array}{l}\text { Pajarito Scientific } \\
\text { Corp. }\end{array}$ & & • & $X$ & $\begin{array}{l}\text { Imaging passive active neutron differential dieaway. High-resolution gamma-ray energy analysis and gamma } \\
\text { spectrometry. Isotopic analysis capability. The system is mounted in its own trailer designed for drums and SWBs. }\end{array}$ \\
\hline $\begin{array}{l}\text { Scientific Ecology } \\
\text { Group }\end{array}$ & $\mathrm{X}$ & & & $\begin{array}{l}\text { Prompt gamma neutron. In a conceptual design stage; needs funding. Working with Westinghouse Science \& } \\
\text { Technology Center, Pittsburgh. }\end{array}$ \\
\hline Visual Exam & & & & 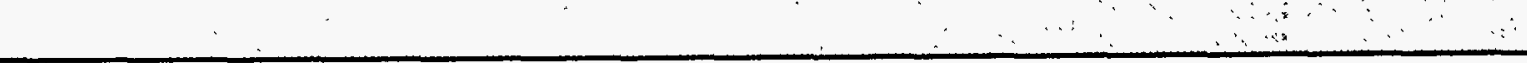 \\
\hline Los Alamos & & $\mathrm{X}$ & & Two waste characterization gloveboxes for drums. Includes a dolly for tilting drum into glovebox. Portable system. \\
\hline $\begin{array}{l}\text { Lockheed Martin } \\
\text { Specialty } \\
\text { Components/Bio- } \\
\text { Imaging Research, } \\
\text { Inc. }\end{array}$ & & $X$ & & $\begin{array}{l}\text { Mobile analytical laboratory is being mounted in its own trailer. Will be field tested on heterogenuus waste in drums at } \\
\text { Idaho (schedule not established). }\end{array}$ \\
\hline NFT Inc. & $\mathrm{X}$ & & & $\begin{array}{l}\text { Glovebox line for removing drum contents for visual exams. Can repackage waste into a drum. Mounted in trailer. } \\
\text { HEPA filtration on glovebox line. }\end{array}$ \\
\hline
\end{tabular}


DOE/NTP-96-1202, Rev.0

Table 10.1 - Mobile System Capabilities of DOE Sites and U.S. Vendors

\begin{tabular}{|c|c|c|c|c|}
\hline \multirow[t]{2}{*}{ CAPABILITY } & \multicolumn{3}{|c|}{ STATUS } & \multirow[t]{2}{*}{ REMARKS } \\
\hline & $\begin{array}{l}\text { Concept- } \\
\text { ual } \\
\text { Design }\end{array}$ & $\begin{array}{l}\text { Proto- } \\
\text { type }\end{array}$ & $\begin{array}{l}\text { Ready } \\
\text { to Go }\end{array}$ & \\
\hline \multicolumn{5}{|l|}{ Headspace Gas Analysis } \\
\hline Idaho & & & $X$ & $\begin{array}{l}\text { Fourier transform infrared spectrometer and residual gas analyzer from Applied Automation. Portable, mounted on a } \\
\text { cabinet on wheels. Will be field demonstrated at Lawrence Livermore, Los Alamos, and Savannah River. Can analyze } \\
\text { listed VOCs and hydrogen for complete headspace gas analysis. }\end{array}$ \\
\hline Los Alamos & & $\mathrm{X}$ & & Drum venting system capable of analyzing for hydrogen. Not capable of complete headspace gas analysis. \\
\hline Applied Automation & $\mathrm{x}$ & & & $\begin{array}{l}\text { Applied Automation, in conjunction with Idaho, developed a headspace gas analysis technique that uses a residual gas } \\
\text { analyzer. The analyzer can be integrated into the Fourier transform infrared spectroscopy system that is contained in a } \\
\text { portable stainless-steel cabinet. Because of the success of the field tests at Idaho with TRU wastes, the Carlsbad Area } \\
\text { Office has directed sites to incorporate Fourier transform infrared spectroscopy systems into their QAPjPs. }\end{array}$ \\
\hline Entropy, Inc. & $X$ & & & $\begin{array}{l}\text { Although this system is commercially available, application to DOE TRU waste remains in the conceptual phase. To } \\
\text { date, no application to or field testing with TRU waste. }\end{array}$ \\
\hline NFT Inc. & & & $x$ & $\begin{array}{l}\text { Drum venting system capable of analyzing for hydrogen and total VOCs. Not capable of complete headspace gas } \\
\text { analysis but can be easily modified with a Fourier transform infrared spectrometer for WIPP-compliance analysis. } \\
\text { Field demonstrated at Savannah River. }\end{array}$ \\
\hline \multicolumn{5}{|l|}{ RCRA Sampling/Coring } \\
\hline Los Alamos & & $\mathrm{X}$ & & $\begin{array}{l}\text { Cemented waste coring and RCRA sampling capability is mounted in the glovebox, which will be mounted in a } \\
\text { transportainer in FY 1997. Coring and sampling capability has been demonstrated on Los Alamos waste in drums in } \\
\text { the size reduction facility. }\end{array}$ \\
\hline $\begin{array}{l}\text { Lockheed Martin } \\
\text { Speciality } \\
\text { Components/Bio- } \\
\text { Imaging Research, } \\
\text { Inc. }\end{array}$ & & $\mathrm{X}$ & & $\begin{array}{l}\text { The mobile analytical laboratory has coring and sampling capability. The equipment is mounted in a glovebox and is } \\
\text { being mounted in a trailer now. It will be tested on cemented waste and sludge in drums at Idaho (schedule not yet } \\
\text { established). }\end{array}$ \\
\hline NFT Inc. & & & $x$ & $\begin{array}{l}\text { Drum coring machine that provides core samples of hard or soft drum waste for physical and chemical analysis. } \\
\text { Samples are taken to ensure that all drum contents are represented. Transportable unit has been field tested at Rocky } \\
\text { Flats with good results. }\end{array}$ \\
\hline
\end{tabular}


Table 10.1 - Mobile System Capabilities of DOE Sites and U.S. Vendors

\begin{tabular}{|c|c|c|c|c|}
\hline \multirow[t]{2}{*}{ CAPABILITY } & \multicolumn{3}{|c|}{ STATUS } & \multirow[t]{2}{*}{ REMARKS } \\
\hline & $\begin{array}{l}\text { Concept- } \\
\text { ual } \\
\text { Design }\end{array}$ & $\begin{array}{l}\text { Proto- } \\
\text { type }\end{array}$ & $\begin{array}{l}\text { Ready } \\
\text { to Go }\end{array}$ & \\
\hline RCRA Analysis & & & & 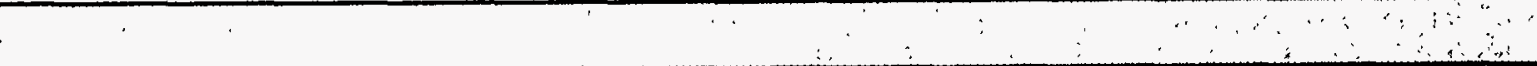 \\
\hline Ames Laboratory & & $X$ & & $\begin{array}{l}\text { Laser ablation-inductively coupled plasma atomic emission spectroscopy for total metal analysis. Trailer is available; } \\
\text { instrument is not being used because it is old technology. }\end{array}$ \\
\hline $\begin{array}{l}\text { Lockheed Martin } \\
\text { Speciality } \\
\text { Components/Bio- } \\
\text { Imaging Research, } \\
\text { Inc. }\end{array}$ & & $x$ & & $\begin{array}{l}\text { The mobile analytical laboratory has RCRA analysis capability. This equipment is contained in a glovebox and will be } \\
\text { mounted in a trailer. It will be field demonstrated on cemented waste and sludge samples taken from Idaho waste } \\
\text { (schedule not yet established). }\end{array}$ \\
\hline $\begin{array}{l}\text { R.F. Weston } \\
\text { Mobile/Transport } \\
\text { Analytical Lab }\end{array}$ & $\mathrm{X}$ & & & $\begin{array}{l}\text { RCRA characterization; EPTox on total metals, VOC analysis, explosives, polychlorinated biphenyl analysis. Gas } \\
\text { chromatography/ mass spectroscopy system; high-pressure liquid chromatography; infrared spectrometers. No } \\
\text { experience with TRU mixed waste; experience with environmental restoration field screening methods } \\
\text { (nonradioactive). Have used a } 12^{\prime} \text { x } 60^{\prime} \text { trailer to transport mobile analytical equipment. Mobile capability not } \\
\text { currently available. }\end{array}$ \\
\hline Repackaging & & & 6 & $\because \div \quad \cdots$ \\
\hline Los Alamos & & $X$ & & $\begin{array}{l}\text { The waste characterization glovebox can be used for drummed waste repackaging and is portable. It will be mounted } \\
\text { on a transportainer in FY } 1997 \text {. }\end{array}$ \\
\hline $\begin{array}{l}\text { Lockheed Martin } \\
\text { Speciality } \\
\text { Components/Bio- } \\
\text { Imaging Research, } \\
\text { Inc. }\end{array}$ & & $X$ & & $\begin{array}{l}\text { The mobile analytical laboratory has repackaging capability for drummed waste. The glovebox is being mounted in a } \\
\text { trailer. It will be field demonstrated on combustible waste at Idaho (schedule not established yet). }\end{array}$ \\
\hline NFT Inc. & $x$ & & & $\begin{array}{l}\text { Glovebox for removing the contents of a drum and repackaging into a drum. Mounted in a trailer. Glovebox has } \\
\text { HEPA filtration. }\end{array}$ \\
\hline D \& D/Treatment & & & & \\
\hline Nuclear Fuel Services & & & $x$ & $\begin{array}{l}\text { The decontamination, volume reduction (cutting/compaction), and passive neutron NDA systems have been field } \\
\text { demonstrated as a fixed unit. Engineering drawings are complete to make the system transportable upon award of } \\
\text { contract. }\end{array}$ \\
\hline
\end{tabular}


Table 10.1 - Mobile System Capabilities of DOE Sites and U.S. Vendors

\begin{tabular}{|c|c|c|c|c|}
\hline \multirow[t]{2}{*}{ CAPABILITY } & \multicolumn{3}{|c|}{ STATUS } & \multirow[t]{2}{*}{ REMARKS } \\
\hline & $\begin{array}{l}\text { Concept- } \\
\text { ual } \\
\text { Design }\end{array}$ & $\begin{array}{l}\text { Proto- } \\
\text { type }\end{array}$ & $\begin{array}{l}\text { Ready } \\
\text { to Go }\end{array}$ & \\
\hline $\begin{array}{l}\text { Stock Equipment } \\
\text { Company }\end{array}$ & & & $\mathrm{X}$ & $\begin{array}{l}\text { Shredder/compactor, solidification system, and remote drum capper are portable and have been field demonstrated on } \\
\text { LLW at Paducah and Argonne-East. For drums and SWBs. }\end{array}$ \\
\hline Container Products & & & $\mathrm{X}$ & $\begin{array}{l}\text { Mobile decontamination system S/SSAP } 3000 \text { Series. Mounted in a trailer that is a DOT Type A container. System is } \\
\text { HEPA filtered. Have experience decontaminating TRU waste. }\end{array}$ \\
\hline Drum Venting & & & & 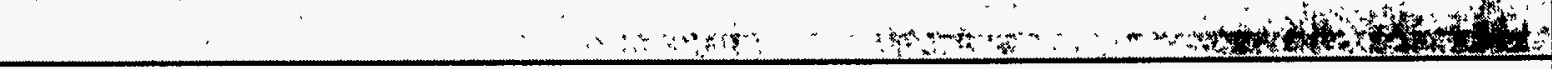 \\
\hline Los Alamos & & $\mathrm{X}$ & & The drum venting system has been constructed. The system is portable. \\
\hline Americlean, Inc. & $\mathrm{X}$ & & & $\begin{array}{l}\text { Americlean, Inc. has developed a drum punch that could be adapted for drum venting in a hot cell environment. It is } \\
\text { relatively low maintenance and low cost. The device is currently available and has extensive field application in } \\
\text { nonradioactive environments. There are currently no plans to perform field testing for TRU applications. Has received } \\
\text { National Stock Number } 4250-01-432-7903 \text { for drum punching device. }\end{array}$ \\
\hline $\begin{array}{l}\text { Lockheed Martin } \\
\text { Speciality } \\
\text { Components/ Bio- } \\
\text { Imaging Research, } \\
\text { Inc. }\end{array}$ & $\mathrm{X}$ & & & A drum venting system is planned. \\
\hline NFT Inc. & & & $\mathrm{X}$ & The drum venting system is being field demonstrated at Savannah River. The system is portable. \\
\hline $\begin{array}{l}\text { TRUPACT-II } \\
\text { Load/Unload }\end{array}$ & & & & is \\
\hline WIPP/Westinghouse & & & $\mathrm{X}$ & $\begin{array}{l}\text { Two of the three TRUPACT-II mobile loading units are located at the WIPP site and are available for site use. The } \\
\text { third unit is in use at Argonne National Laboratory - West and the Idaho National Engineering Laboratory and will not } \\
\text { be available until } 2003 \text {. The site needs a crane or forklift and capability to band or shrinkwrap drums in a 7-pack. For } \\
\text { drums and SWBs. }\end{array}$ \\
\hline
\end{tabular}


Table 10.1 - Mobile System Capabilities of DOE Sites and U.S. Vendors

\begin{tabular}{|c|c|c|c|c|}
\hline \multirow[t]{2}{*}{ CAPABILITY } & \multicolumn{3}{|c|}{ STATUS } & \multirow[t]{2}{*}{ REMARKS } \\
\hline & $\begin{array}{l}\text { Concept- } \\
\text { ual } \\
\text { Design }\end{array}$ & $\begin{array}{l}\text { Proto- } \\
\text { type }\end{array}$ & $\begin{array}{l}\text { Ready } \\
\text { to Go }\end{array}$ & \\
\hline Radiochemistry & & & & 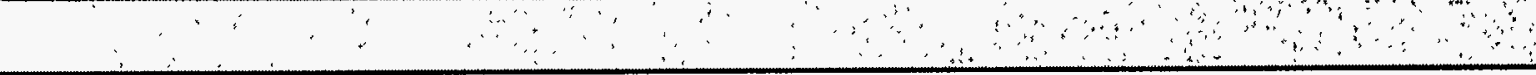 \\
\hline $\begin{array}{l}\text { Lockheed Martin } \\
\text { Speciality } \\
\text { Components/Bio- } \\
\text { Imaging Research, } \\
\text { Inc. }\end{array}$ & & $\mathrm{X}$ & & $\begin{array}{l}\text { The mobile analytical laboratory has radiochemistry capability. This equipment is housed in a glovebox and will be } \\
\text { mounted in a trailer. It will be field demonstrated on waste samples taken from Idaho waste (schedule not established } \\
\text { yet). }\end{array}$ \\
\hline Data Validation & & & & 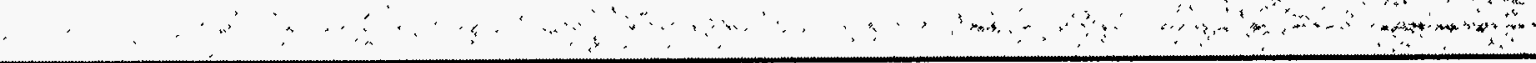 \\
\hline $\begin{array}{l}\text { Esparza Data } \\
\text { Validation Services }\end{array}$ & & N/A & & $\begin{array}{l}\text { Produce data interpretation and validation report on radiological data to satisfy EPA Consent Orders at Idaho. } \\
\text { Experience also includes lab QA at Idaho. }\end{array}$ \\
\hline $\begin{array}{l}\text { Wastren, Inc. } \\
\text { Analytical Data } \\
\text { Management }\end{array}$ & & N/A & & $\begin{array}{l}\text { Data validation is subcontracted under another company. Wastren has experience in sampling and analysis plans and } \\
\text { waste certification for TRU waste at Rocky Flats. }\end{array}$ \\
\hline DoT Type A Containers & & & & $\therefore, \cdots, \cdots, \therefore, \cdots$ \\
\hline $\begin{array}{l}\text { Container Products } \\
\text { Corporation }\end{array}$ & & & $\mathrm{X}$ & $\begin{array}{l}\text { Certified DOT Type A containers that can house large pieces of portable TRU-contaminated equipment, facilitating the } \\
\text { transfer of mobile systems from site to site. Contaminated containers can be easily decontaminated. }\end{array}$ \\
\hline Mobile Technical Services & & & . & 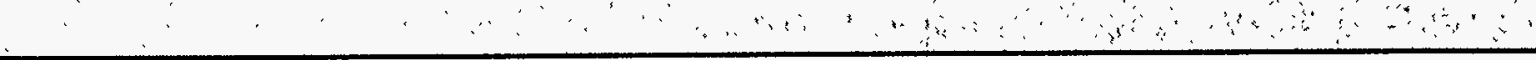 \\
\hline $\begin{array}{l}\text { Rogers \& Associates } \\
\text { Engineering }\end{array}$ & & & $\mathrm{X}$ & $\begin{array}{l}\text { Safety analysis, risk assessments, worker protection, and computer software development. Services also in systems } \\
\text { engineering and tools to support design of individual characterization capabilities, the configuration and deployment of } \\
\text { the system, and overall process control. }\end{array}$ \\
\hline
\end{tabular}


Table 10.2 - Mobile System Capabilities of Foreign Vendors

\begin{tabular}{|c|c|c|c|c|}
\hline \multirow[t]{2}{*}{ CAPABILITY } & \multicolumn{3}{|c|}{ STATUS } & \multirow[t]{2}{*}{ REMARKS } \\
\hline & $\begin{array}{c}\text { Concep- } \\
\text { tual } \\
\text { Design }\end{array}$ & $\begin{array}{l}\text { Proto- } \\
\text { type }\end{array}$ & $\begin{array}{l}\text { Ready } \\
\text { to Go }\end{array}$ & \\
\hline Characterization & & & & 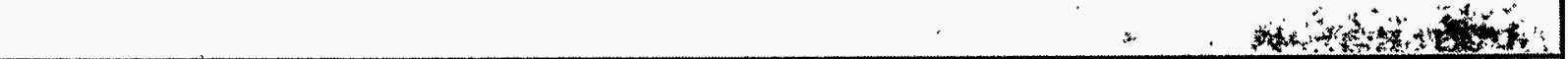 \\
\hline NDE & & & & 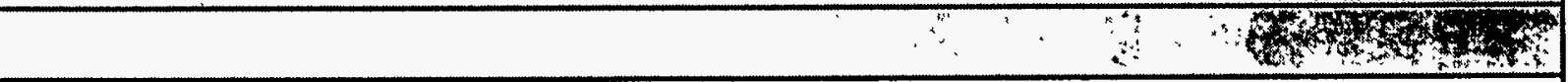 \\
\hline $\begin{array}{l}\text { WEIR } \\
\text { Hopkinsons LTD } \\
\text { (United Kingdom) }\end{array}$ & N/A & N/A & N/A & $\begin{array}{l}\text { WEIR-Hopkinsons is the only valve company in the UK with its own foundry. It manufactures valves, } \\
\text { actuators, and related equipment. They have extensive destructive and nondestructive metallurgical materials } \\
\text { testing facilities, but these facilities are not portable or mobile. WEIR does not manufacture NDE systems; } \\
\text { rather, they provide services for determining failure of valves and related components. }\end{array}$ \\
\hline $\begin{array}{l}\text { AECL-Chalk River } \\
\text { (Canada) }\end{array}$ & N/A & N/A & N/A & $\begin{array}{l}\text { AECL-Chalk River does not manufacture mobile or portable NDE equipment. Their equipment thus has no } \\
\text { direct application to the scope of this study or this document. }\end{array}$ \\
\hline NDA & & & & 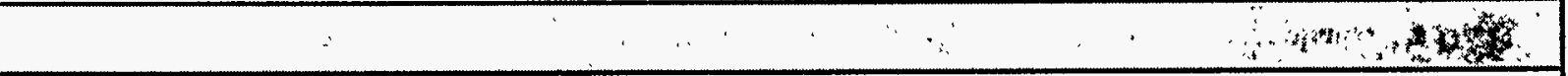 \\
\hline $\begin{array}{l}\text { Nukem } \\
\text { (Germany) }\end{array}$ & & & $x$ & $\begin{array}{l}\text { Nukem has developed and engineered an NDA waste drum measurement facility called GME. The GME was } \\
\text { developed in Germany in order to completely characterize waste drums for final disposition in Switzerland. } \\
\text { The GME is fully transportable, automatically controlled, and compact. It measures total package mass, surface } \\
\text { dose rates, radial dose rates, and maximum surface dose rates and identifies hot spots. It simultaneously } \\
\text { performs quantitative and qualitative gamma emitter determination. It can accommodate various sizes of drums } \\
\text { containing radioactive metals, heterogeneous wastes, and organics. The GME is a fully developed and } \\
\text { functional device and is commercially available. }\end{array}$ \\
\hline $\begin{array}{l}\text { Rados } \\
\text { (USA and Germany) }\end{array}$ & & & $\mathrm{X}$ & $\begin{array}{l}\text { Rados of Germany, with offices in Columbia, Maryland, has developed a highly versatile and comprehensive } \\
\text { drum assay machine called the Rados HI } 3640 \text { Waste Measurement System. It performs complete gamma } \\
\text { measurement and gamma spectroscopy for various types of low-level and some intermediate-level radioactive } \\
\text { wastes. It is fully mobile and portable and can be easily integrated into other process functions. It uses various } \\
\text { scintillation counters to assay 55-gallon drums containing metal scrap, reactor filter material (such as resins), } \\
\text { fluorescent materials, and paper wastes. The unit has been extensively field tested and is commercia!ly } \\
\text { available. }\end{array}$ \\
\hline $\begin{array}{l}\text { Münchener } \\
\text { Apparatebau für } \\
\text { Elektronische Geräte } \\
\text { GmbH (Germany) }\end{array}$ & & & $X$ & $\begin{array}{l}\text { MAB has developed a drum measuring unit that performs complete gamma scanning. It is fully mobile and is } \\
\text { housed in a container comparable to a DOT Type A container. The device can perform its functions } \\
\text { independently or can be integrated into other measurement systems. It has been extensively field tested and } \\
\text { used and is commercially available. It can accommodate a variety of waste forms with a high degree of } \\
\text { measurement accuracy. }\end{array}$ \\
\hline
\end{tabular}


Table 10.2 - Mobile System Capabilities of Foreign Vendors

\begin{tabular}{|c|c|c|c|c|}
\hline \multirow[t]{2}{*}{ CAPABILITY } & \multicolumn{3}{|c|}{ STATUS } & \multirow[t]{2}{*}{ REMARKS } \\
\hline & $\begin{array}{l}\text { Concep- } \\
\text { tual } \\
\text { Design }\end{array}$ & $\begin{array}{c}\text { Proto- } \\
\text { type }\end{array}$ & $\begin{array}{l}\text { Ready } \\
\text { to Go }\end{array}$ & \\
\hline Incineration & & & & $\therefore \quad \therefore \quad(a+2)$ \\
\hline $\begin{array}{l}\text { Studsvik Radwaste, } \\
\text { AB (Sweden) }\end{array}$ & $\mathrm{x}$ & & & $\begin{array}{l}\text { Studsvik manufactures incinerators that to date are not mobile. These units are primarily intended as vertical- } \\
\text { standing, facility-operated units that are probably not readily adaptable for mobile applications. }\end{array}$ \\
\hline $\begin{array}{l}\text { Headspace Gas } \\
\text { Analysis }\end{array}$ & & & & 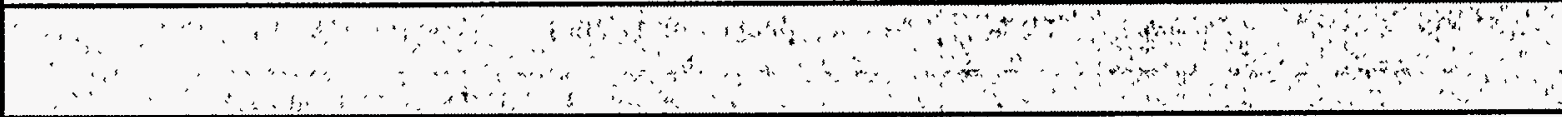 \\
\hline $\begin{array}{l}\text { Thomson \& Nielsen } \\
\text { (Canada) }\end{array}$ & $\mathrm{X}$ & & & $\begin{array}{l}\text { Makers of specialized portable radiation detection devices designed for handheld use or for continuous } \\
\text { movement. Specializes in radon gas detectors, among others types, and can design monitors for gas streams } \\
\text { specific to a particular application or requirement. }\end{array}$ \\
\hline $\begin{array}{l}\text { Decontamination \& } \\
\text { Decommissioning }\end{array}$ & & & & $\therefore \quad \cdots \quad \therefore \quad \therefore$ \\
\hline $\begin{array}{l}\text { Studsvik Radwaste, } \\
\text { AB (Sweden) }\end{array}$ & $\mathrm{x}$ & & & $\begin{array}{l}\text { Studsvik is one of the prominent companies in Europe in the area of D\&D of nuclear power plants. Its D\&D } \\
\text { services are universal and are not specific to mobile waste characterization applications. Their experience lies } \\
\text { primarily within the European nuclear power industry and laboratories. }\end{array}$ \\
\hline
\end{tabular}


DOE/NTP-96-1202, Rev.0

DEPLOYMENT 


\section{PRELIMINARY COST INFORMATION}

For the purposes of this plan and to indicate the possible magnitude of the costs of deploying mobile systems, costs were determined through vendor surveys, from DOE planning documents, and from a traditional construction cost engineering manual. The costs presented are for procuring and operating various mobile systems at DOE sites. Other costs associated with deployment, such as administrative costs, are not treated here. The costs of a generic fixed facility are also presented. For ease of reference, the tables presenting cost information are at the end of this chapter. Options for direct purchase, lease, and privatization through contracts are discussed in Chapter 12.

The cost estimates are based on some general assumptions that may vary greatly depending on the nature and complexity of the waste form; what pieces of equipment are used, how long they are used, and how reliably they perform; and site-specific requirements. The terms of each contract will have to take such variables into account.

The eventual cost of mobile system operations will be influenced by three factors:

- what acquisition options DOE pursues (privatization, through competition; direct purchase; or lease);

- how precisely sites define the specific services they seek from vendors and the timing of those services;

- how efficiently sites configure the staging and processing of their waste streams.

\section{The cost of mobile systems for DOE sites}

An estimate of what it would cost to purchase, operate, and maintain mobile system equipment is presented in Table 11.1. It is not known at this time how many pieces of equipment sites will need for a given technology. For the purposes of Table 11.1, one piece of equipment was assigned to each site that indicated a need for that particular piece of equipment. Information about equipment and maintenance costs, estimated throughput rates, and projected crew sizes was obtained from vendors. The information supplied is necessarily limited, because operating experience at DOE sites is limited. The equipment costs used in Table 11.1 are listed in Table 11.2. The cost of one trailer per piece of equipment is added to the equipment costs to calculate the cost of mobile systems at each site.

Equipment prices for 1996 were escalated by 3 percent to reflect system deployment in Fiscal Year 1997. The investment in mobile systems that DOE and private companies will make together, during the 10-year period from Fiscal Year 1997 through Fiscal Year 2006, is estimated to be $\$ 67.3$ million. This estimate represents the acquisition cost of the equipment and trailers as well as operating and maintenance costs. Accuracy of these estimates are very limited; costs from vendors are therefore considered to have levels of accuracy equivalent to conceptual design. The cost estimates in Table 11.1 specify how long each mobile system component will operate at each site until a fixed facility comes on-line or until waste work-off is completed. 
The estimates presented in this chapter do not inciude administrative costs, such as the costs of preparing, reviewing, and approving the vendor characterization and certification documents and documentation vendors must submit in order to operate at a DOE site; the costs of conducting the Performance Demonstration Program; and indirect operating costs, such as training, health physics, and waste staging.

\section{Fixed facility and equipment costs}

Table 11.2 presents estimates of equipment costs, which are assumed to be identical for both mobile systems and fixed facilities. When more than one vendor quoted costs for one kind of equipment, the cost figures provided by the most experienced vendor were used.

Table 11.3 presents a parametric cost estimate (historical costs used as estimates for specific parameters) of a 49,609 sq. $\mathrm{ft}$. Butler-type building. This cost model was used because the equipment used in waste characterization and handling can be operated efficiently in this type of facility. The building-dimension parameters used are based on the building in the Waste Management Facilities Cost Information for Transuranic Waste (Shropshire et al., INEL-95/0015, Revision 1, 1995). Traditional cost engineering references and methods were used to estimate individual cost. The fixed facility construction and facility equipment cost estimates were developed using Means cost reference guide for construction cost engineering. The equipment costs used in Table 11.3 are taken from Table 11.2. The total estimated fixed facility and equipment cost is $\$ 13,364,400$.

\section{Operating costs}

The preliminary operating costs pertain only to the direct operation of mobile systems and do not take into account site support personnel such as health physics technicians, those supporting waste operations (for box or drum staging and container tracking), and employee training (for example, for site-required health and safety training for mobile system operators). The estimated operating costs that appear in Table 11.1 were calculated based on an hourly rate of $\$ 45 / \mathrm{hr}$ for 2,000 hours/year. (This rate is based on the DOE Albuquerque Operations Office waste management baseline, and is an average across the nine sites administered by that office.) The annual operating cost for a suite of six mobile system components requiring 14 full-time employees is estimated to be $\$ 1,260,000$.

The breakout of operators for each mobile system component based on vendor survey information is:

$\underline{\text { Mobile System }}$

NDE

NDA

Headspace Gas Analysis \& Drum Venting

Visual Examination/Repackaging

RCRA Sampling

TRUPACT-II Loading

\section{Number of Operators}

1

2

3

3

3

2

14 


\section{Maintenance costs}

Maintenance costs were calculated as 2.5 percent of the equipment costs taken from the vendor quotes, which is based on their experience as reported in the vendor surveys. The total maintenance cost for a full suite of mobile system components is $\$ 58,000$ per year using the total equipment cost (without trailers) of $\$ 3,603,000$ from Table 11.2. 
Table 11.1 Preliminary Site-Specific Costs of Purchasing,

Operating, and Maintaining Mobile Systems: Fiscal Years 1997- 2006

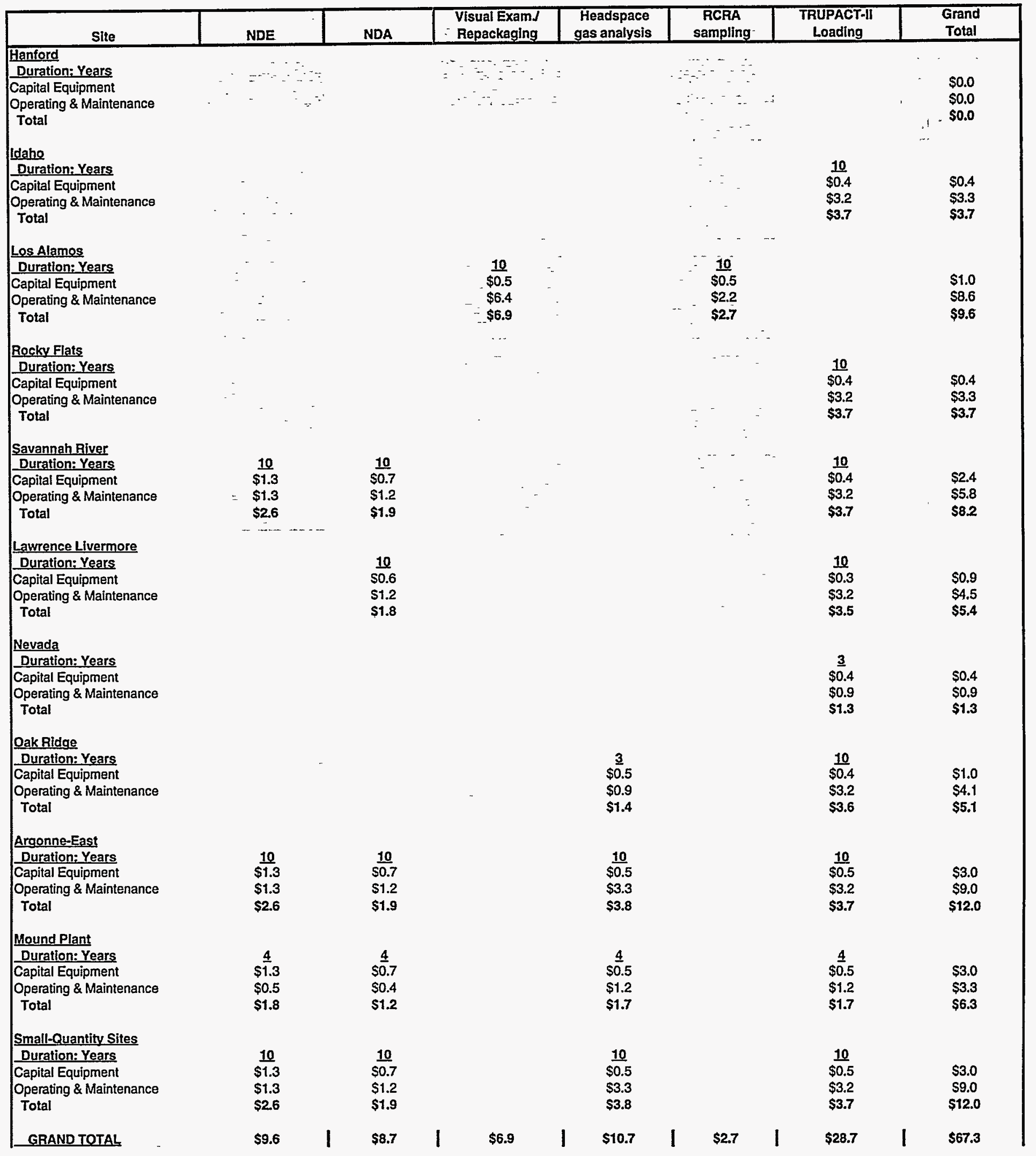

Notes: 1. All totaled costs are roundod up to the nearest So.1 million. 
Table 11.2 - Equipment Costs, Fiscal Year 1996

\begin{tabular}{|c|c|c|c|}
\hline Mobile Equipment & Equipment & Trailer & Cost \\
\hline $\mathrm{NDE}$ & $\$ 850,000$ & $\$ 150,000$ & $\$ 1,000,000$ \\
\hline $\mathrm{NDA}$ & $\$ 380,000$ & $\$ 150,000$ & $\$ 530,000$ \\
\hline $\begin{array}{l}\text { Headspace sampling/analysis; } \\
\text { Drum venting }\end{array}$ & $\begin{array}{l}\$ 375,000 \\
\$ 325,000\end{array}$ & $\begin{array}{l}\$ 150,000 \\
\$ 150,000\end{array}$ & $\begin{array}{l}\$ 525,000 ; \$ 475,000 \\
(\$ 1,000,000)\end{array}$ \\
\hline RCRA sampling glovebox & $\$ 200,000$ & $\$ 150,000$ & $\$ 350,000$ \\
\hline Repackaging & $\$ 350,000$ & $\$ 150,000$ & $\$ 500,000$ \\
\hline \multirow[t]{2}{*}{ TRUPACT-II loading } & 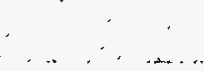 & $\ldots$ & $\$ 223,000$ \\
\hline & $\$ 2,480,000$ & $\$ 900,000$ & $\$ 3,603,000$ \\
\hline
\end{tabular}

* In Table 11.1, the cost of one trailer per piece of equipment is added to the cost of mobile systems for each site. 
Table 11.3 - Fixed Facility

Building and Equipment Costs, Fiscal Year 1996

(\$Thousands)

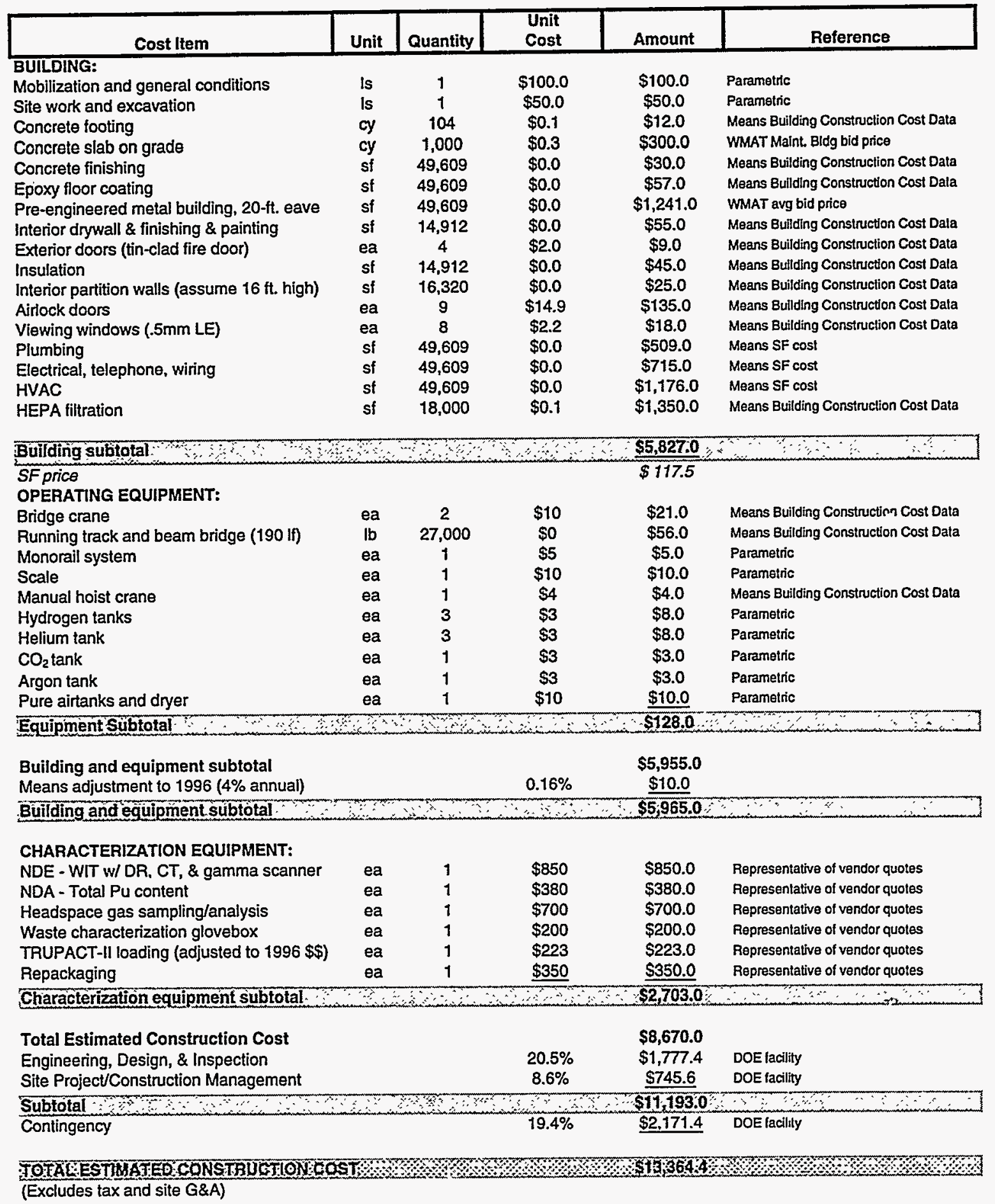

Assumes pre-engineered building shell. Characterization units are modular and are provided on skid-mounted units.

CT. computed tomography. cy, cubic yard; DR, digital radiography: st, square loot: WIT, waste inspection tomography: WMAT. White Mountain Apache Tribe landlill construction 


\section{OPTIONS FOR ACQUIRING MOBILE SYSTEM SERVICES}

This chapter offers basic information about how DOE can acquire mobile services. Specific information about sources and levels of funding will become available as the Federal budget process and DOE decision making unfold.

\section{Basic acquisition options}

Mobile systems are fabricated by vendors in this country and abroad, and by DOE site contractors. DOE can choose from several options for acquiring them:

- direct purchase, with vendor or DOE site personnel operating the system;

- lease, with site or vendor personnel operating the system; and

- privatization, through contracts, with vendor or site personnel operating the system.

In selecting an option, the source and availability of funding were considered. The sources are capital equipment funding and/or operating funding. Capital equipment funds are used to purchase equipment; operating funds are used to lease equipment and to fund contracts. Each option carries advantages and disadvantages.

\section{Direct purchase with capital equipment funding}

Because of the requirements of the Federal budget cycle, capital equipment funding is typically requested at least two years in advance of the date it is needed. Site needs may have changed by the time funding is received, with the consequence that throughout the DOE complex a pool of uncommitted capital equipment funding may accumulate by the end of each fiscal year.

That pool of funds could be tapped for mobile systems, with the approval of the DOE Controller. Requests for funding could originate at sites. Each site would submit a request to its counterpart at their Operations Office. Operations Office financial managers would submit a request for uncommitted capital equipment funds to the Carlsbad Area Office. The Carlsbad Area Office would compile requests for capital equipment and submit a request for funding to the DOE Controller for the entire National TRU Program.

The disadvantage of pursuing a capital equipment funding option is a loss of flexibility in managing funds: capital equipment funding can only be used to acquire capital equipment. If a site needs more funding for capital equipment than it receives or than is available within the DOE complex, it has to exchange its own operating funds for another site's uncommitted capital equipment funding-if another site has uncommitted funding and if DOE managers approve of the exchange. If this exchange could not be made, the acquisition for capital equipment would be delayed until new capital equipment funding becomes available in the next fiscal year. Even if the exchange were possible, a delay of 90 days or more should be expected. 


\section{Lease, with operating funds}

Operating funds are used to lease equipment. Most commonly, under a lease, title to the equipment does not pass to the lessee; but under a lease-purchase agreement it could. Operating funds offer managers the flexibility to allocate funds between activities and procurement that support waste management without having to acquire equipment permanently. When leased equipment is no longer needed, the lessor removes it.

\section{Privatization through contracts}

Privatization involves competition for contracts to deliver a specific product or service; payment is made upon delivery. Privatization would be initiated through publication of a Request for Information in the Commerce Business Daily soliciting information from firms interested in providing mobile services. Multiple contracts could be awarded under a Basic Ordering Agreement with pre-qualified vendors. The mobile system contractor would furnish all required personnel, equipment, and facilities to carry out needed operations. Firms would be responsible for safe operation of their equipment and for the quality of data produced. They would perform under DOE oversight. Operating funds will be used to pay for privatization activities.

Using the DOE Environmental Management Privatization Guidance to acquire mobile systems could reduce the cost of the mobile system initiative, because by its nature the initiative lends itself well to unit price competition:

- the volume of TRU waste that must be processed under the contract is known;

- the rate at which waste will be delivered to the vendor is known;

- the scope and nature of the operations needed are quantifiable and measurable; and

- the regulatory framework and requirements are well-defined.

Moreover, the vendors surveyed in developing this plan are all eager to earn a return on their investment in research, development, and fabrication of mobile systems.

Given these conditions, DOE should be able to negotiate unit rates that are cost-effective and equitable to all parties. The rates can be based on volumes of waste to be handled; vendors could be paid after DOE accepts their services as complete and satisfactory.

\section{Advantages of privatization}

Privatization of mobile systems will save money in the short-term through avoidance of capital acquisition. The savings will be realized when the unit prices negotiated with commercial vendors compare favorably with the "cost of doing business" at a DOE site. The cost of doing business includes indirect costs that are added to commercial vendor prices by the management and operating contractors and universities that manage DOE sites. Indirect costs include organization overhead and institutional general and administrative burden charges. At some DOE sites the additional cost of doing business can run from 40 percent higher than what private vendors charge for equipment, operating, and maintenance-up to nearly double their charges. Because of these advantages, privatization by way of contracts is the preferred option. 


\section{FOR VENDORS: STEPS TOWARD DOE CONTRACTS}

This chapter summarizes how vendors can qualify for competitive bidding to provide mobile system services to DOE sites. Sources of information identified below are listed under "References" at the end of this plan. Steps vendors can take include the following:

- To identify site needs for mobile systems, examine Tables 9.2 and 9.3 in this plan.

- From the information clearinghouse, obtain the following documents, discussed in Chapters 3 and 7, and become familiar with the contents:

- Waste Acceptance Criteria for the Waste Isolation Pilot Plant, Rev. 5

- National Transuranic Waste Management Plan, Rev. 0

- Transuranic Waste Characterization Quality Assurance Program Plan, Rev. 0

- DOE Waste Treatability Group Guidance, Rev. 0

- "Use of Mobile Systems for Waste Characterization," National TRU Program Technical Position, Draft (Rev.1)

- $\quad$ Performance Demonstration Program plans, as applicable.

- To identify the specific waste forms and quantities a system could address at each site, use the Transuranic Waste Baseline Inventory Report, Rev. $2 .^{14}$

- To identify appropriate site contacts and to approach sites and the Carlsbad Area Office with a marketing plan, contact the information clearinghouse.

- To learn about funding for technology development, contact the Carlsbad Area Office or site managers for technology development or TRU waste characterization.

- To obtain guidance for meeting a site's requirements for authorization to operate, contact the site.

- Prepare vendor characterization and certification documents that show how a system meets the requirements applicable to it and submit it to the Carlsbad Area Office for approval.

- If a system is covered by a Performance Demonstration Program (NDA, headspace gas analysis, and RCRA analysis), enroll in it.

${ }^{14}$ Transuranic Waste Baseline Inventory Report, Revision 2, CAO-95-1121. DOE - Carlsbad Area Office, 1995. 


\section{STRATEGIES FOR DEPLOYING MOBILE SYSTEMS}

The National Transuranic Waste Management Plan identifies significant site needs for mobile capabilities, and those capabilities are available in the marketplace. Assessing this information has given an understanding of what it will take to expedite the deployment of mobile systems under a privatization strategy.

\section{Matching site needs with vendor capabilities}

Making the match between site needs and vendor capabilities-quickly and on terms that are costeffective-is the challenge. The substantial benefits offered by privatizing the use of mobile systems can be realized as DOE recognizes and responds to the needs of the private sector. These needs include:

- a central point of contact within DOE to which they can provide information about their capabilities and from which they can obtain guidance on site needs and requirements;

- a minimum of required paperwork, and rapid turnaround on review and approval of required documentation and contract mechanisms;

- a clear definition of what is required to meet the requirements of the WIPP Waste Acceptance Criteria; and

- a clear definition of what is required to meet the high standards that sites have set for safe operations and full regulatory compliance within their boundaries.

Another key to success will be careful definition of site needs and careful configuration of waste staging and processing operations to optimize the flow of waste. Other opportunities for meeting site needs lie in future expansion of the suite of mobile capabilities through technology development. And still others may lie within the DOE complex itself: although sites' mobile capabilities are at present limited, some sites may be able to share some capability. As the mobile system initiative builds momentum and its value is recognized, demand for mobile services will grow.

\section{The elements of a strategy}

To arrive at a rough indication of overall National TRU Program needs, information from Table 9.3, which identifies site needs for mobile capabilities, was merged with Table 10.1, which identifies the capabilities of DOE sites and U.S. vendors. (The capabilities of foreign vendors were not included because their mobile systems cannot be considered readily available: their use by DOE will require an assessment of contractual requirements.) Table 14.1 presents the results. 
Table 14.1 - Near-Term Opportunities to Expand Mobile System Capabilities

\begin{tabular}{|c|c|c|c|c|c|}
\hline \multirow{2}{*}{ Mobile Systems } & \multirow{2}{*}{$\begin{array}{l}\text { Number of Sites } \\
\text { Needing } \\
\text { Additional } \\
\text { Mobile Systems }\end{array}$} & \multicolumn{3}{|c|}{$\begin{array}{c}\text { Number of U.S. Vendor and DOE Mobile } \\
\text { Systems Available }\end{array}$} & \multirow{2}{*}{$\begin{array}{c}\text { Difference between Number of Sites } \\
\text { Needing Mobile Systems } \\
\text { and the Number of Mobile Systems } \\
\text { Ready To Go }\end{array}$} \\
\hline & & $\begin{array}{l}\text { Ready to } \\
\text { Go }\end{array}$ & Prototype & $\begin{array}{l}\text { Conceptual } \\
\text { Design* }\end{array}$ & \\
\hline \multicolumn{6}{|l|}{ CHARACTERIZATION } \\
\hline NDE & 4 & 3 & 1 & 4 & 1 \\
\hline NDA & 5 & 4 & 2 & 3 & $\mathbf{1}$ \\
\hline Visual Examination & 1 & 1 & 2 & 2 & \\
\hline $\begin{array}{l}\text { Headspace Gas } \\
\text { Sampling and Total } \\
\text { VOC Analysis }\end{array}$ & 5 & 2 & 1 & 2 & 3 \\
\hline $\begin{array}{l}\text { RCRA Sampling } \\
\text { and Analysis }\end{array}$ & 2 & 1 & 3 & $\mathbf{1}$ & $\mathbf{1}$ \\
\hline \multicolumn{6}{|l|}{ REPACKAGING } \\
\hline TREATMENT & & 3 & & & \\
\hline DRUM VENTING & & 1 & 중 & 3 & $\cdots$ \\
\hline TRUPACT-II LOADING & 9 & 3 & & & 6 \\
\hline
\end{tabular}

* Los Alamos capabilities listed in Table 10.1 as demonstrated/prototype are in the conceptual design column here because the design, not the capability, is available. 


\section{Role of the Carlsbad Area Office}

The Carlsbad Area Office will make the matches suggested by Table 14.1, serving as a coordinator and source of guidance, technical expertise, and information; fostering technology development; identifying sources of funding; and in many other programmatic ways helping sites and vendors realize the benefits of the mobile system option. The Carlsbad Area Office is responsible for ensuring the timely disposal of TRU waste; however, it cannot ensure success of the mobile system initiative without the participation of sites and vendors. From the analysis that underlies this plan, steps have been identified that all parties can take to advance the initiative.

Some of the steps identified below will be concurrent; some are for the near-term; some will be continuing; some are for the long-term.

- Quantify sites' needs. For each site determine how many mobile units are needed to meet the work-off schedule, taking into account the volume of TRU waste to be processed and vendor throughput rates.

- Prioritize sites' needs using the National Transuranic Waste Management Plan.

- Issue Request for Proposal/Information. Having quantified and prioritized site needs, a Request for Information or a Request for Proposal will elicit from vendors specific information about the costs and availability of mobile systems.

- Budget for contracting. Using vendor responses and quantification and prioritization of site needs, the cost to pursue contracting will be estimated.

- Integrate this initiative with DOE HQ privatization initiatives. Prepare and submit DOE Environmental Management privatization packages for complex-wide contracting and deployment of mobile systems.

- Foster technology development. Opportunities to foster technology development will be identified to expand and improve mobile capabilities. As technology needs are identified, the Carlsbad Area Office will work with sites and DOE's Environmental Management EM-50 program to select technology development proposals for fast-tracking.

- Facilitate sharing among sites. Determine the extent to which sites can share their own mobile system capabilities.

- Develop program support and guidance. To support the mobile system initiative:

- develop detailed plans, schedules, and budgets;

- develop working relationships with the parties who have a stake in this initiative;

- $\quad$ issue formal guidance to help vendors comply with applicable requirements;

- $\quad$ help sites assess vendor capabilities for specific tasks and determine how best to configure mobile operations; 
- facilitate sharing among sites by coordinating and scheduling deployment of DOEowned mobile systems;

- $\quad$ track and report mobile system performance and costs; and

- $\quad$ monitor sites' new and changing needs for mobile systems.

- Determine contractual requirements for foreign vendors.

- Determine what other TRU wastes can be processed by mobile systems. The focus of this plan is contact-handled TRU waste in 55-gallon drums and standard waste boxes. The total TRU waste inventory contains large volumes of TRU waste in other containers. Factors affecting mobile system processing capability include the type of waste containers, waste forms, radionuclides present, and radiation levels. Mobile capabilities-both those existing and those in the prototype and conceptual stages-will be assessed to determine what other TRU wastes they are suited for.

Next steps for sites

- Prepare site authorization guidance. Sites, either as a group or individually, should prepare an authorization guidance for vendors so that vendors can fully meet health, safety, environmental, quality assurance, safeguards and security, and secondary waste-processing requirements in the shortest time with the least administrative cost to both parties. For sites that work together to prepare a single authorization guidance document, the working-group approach used by the Albuquerque Operations Office Mixed Waste Treatment program, described in Chapter 8, offers a useful model.

Next steps for vendors

- Vendors can follow the steps outlined in Chapter 13 to pursue contracts by working through the Carlsbad Area Office.

\section{Communication among all parties}

Over time, the quality and timeliness of the information that sites and vendors provide to the Carlsbad Area Office, the ability to share that information widely, and resourcefulness in using it will shape the outcome of the mobile system initiative.

- The Carlsbad Area Office will expand the information clearinghouse on mobile capabilities and site needs maintained by its Technical Assistance Contractor in Carlsbad, New Mexico. 
The contact for the clearinghouse is,

John F. Suermann

Manager - Waste Characterization

Carlsbad Area Office

Telephone: 505-234-7475

Fax: 505-234-0707

E-mail: suermaj@wipp.carlsbad.nm.us.

The clearinghouse will establish a link to the WIPP WEB home page as a ready source of information on mobile systems.

- Sites and vendors should use the information clearinghouse:

- $\quad$ Sites can contact it for information on vendors listed in Table 10.1.

- Sites can provide updated information on mobile system needs, as these change.

- As needs for mobile capabilities change, sites can alert the clearinghouse so that all vendors will have ready access to this information.

- Sites can share results of demonstrations of mobile systems through the clearinghouse.

- Vendors can use it to learn about contracting opportunities and to provide current information about their capabilities that sites can use. 


\section{LIST OF FIGURES}

Figure ES - 1

Figures $4.1-4.3$
Major and Small-Quantity Sites

Examples of Mobile Systems
4

$13-15$ 


\section{LIST OF TABLES}

Table 9.1 TRU Waste Processing Capabilities: Fixed Facilities (Existing and Planned)

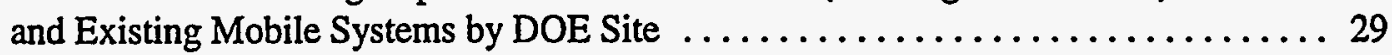

Table 9.2 Potential Use of Additional Mobile Systems Based on Site Needs $\ldots \ldots \ldots \ldots . \ldots 30$

Table 9.3 Number of Sites Needing Additional Mobile Systems:

Fiscal Years $1997-2006$............................... 33

Table $10.1 \quad$ Mobile System Capabilities of DOE Sites and U.S. Vendors $\ldots \ldots \ldots \ldots \ldots$

Table 10.2 Mobile System Capabilities of Foreign Vendors $\ldots \ldots \ldots \ldots \ldots \ldots \ldots \ldots$

Table 11.1 Preliminary Site-Specific Costs of Purchasing, Operating, and Maintaining Mobile Systems: Fiscal Years $1997-2006 \ldots \ldots \ldots \ldots \ldots \ldots \ldots \ldots \ldots . \ldots . \ldots 4$

Table $11.2 \quad$ Equipment Costs, Fiscal Year $1996 \ldots \ldots \ldots \ldots \ldots \ldots \ldots \ldots \ldots \ldots \ldots$

Table 11.3 Fixed Facility Building and Equipment Costs, Fiscal Year $1996 \ldots \ldots \ldots \ldots \ldots$

Table $14.1 \quad$ Near-Term Opportunities to Expand Mobile System Capabilities ............ 56 


\section{LIST OF ACRONYMS}

CFR

D\&D

DOE

DOT

FTE

HEPA

LLW

NDA

NDE

NEPA

PDP

QAVC

QAPjP

QAPP

RCRA

RTR

SWB

TRAMPAC

TRU

TRUPACT-II

VOC

WIPP
Code of Federal Regulations

decontamination and decommissioning

U.S. Department of Energy

U.S. Department of Transportation

full-time equivalent

high-efficiency particulate air

low-level waste

nondestructive assay

nondestructive examination

National Environmental Policy Act

Performance Demonstration Program

quality assurance/quality control

Quality Assurance Project Plan

Quality Assurance Program Plan

Resource Conservation and Recovery Act

real-time radiography

standard waste box

TRUPACT-II Authorized Methods for Payload Control transuranic

transuranic package transporter

volatile organic compound

Waste Isolation Pilot Plant 


\begin{tabular}{|c|c|}
\hline Term & Definition \\
\hline $\begin{array}{l}\text { Atomic Emission } \\
\text { Spectroscopy }\end{array}$ & $\begin{array}{l}\text { A spectroscopic analytical technique that identifies and quantifies the trace metals } \\
\text { present in the waste. The technique depends on the measurement of discrete photons } \\
\text { emitted by the elemental metal from an ionized or electronically excited state. }\end{array}$ \\
\hline Characterization & $\begin{array}{l}\text { Sampling, monitoring, and analysis-whether by review of process knowledge, } \\
\text { nondestructive examination, nondestructive assay radiochemistry, headspace gas } \\
\text { analysis or chemical analysis of the volatile or semi-volatile organic compounds or } \\
\text { metals-to identify and quantify the constituents of a waste material. }\end{array}$ \\
\hline Computed Tomography & $\begin{array}{l}\text { The computer-aided reconstruction of a radiographic image of an object in two or } \\
\text { three dimensions. The image is reconstructed from many individual exposures of the } \\
\text { sample taken in several different planes. The technique applies to neutron } \\
\text { radiography as well as x-radiography. }\end{array}$ \\
\hline Data Validation & $\begin{array}{l}\text { An assessment of the general adequacy and accuracy of a data set and of its } \\
\text { compliance with a list of specific requirements. }\end{array}$ \\
\hline DOT Type A Package & $\begin{array}{l}\text { Defined in } 49 \text { CFR } 173.403 \text {. Its use does not require competent authority approval } \\
\text { because its contents are limited to the } A_{1} \text { and } A_{2} \text { radionuclides listed in DOE } \\
\text { regulations ( } 49 \text { CFR } 173.435 \text { ). Specification } 7 \mathrm{~A} \text { containers will be used to package } \\
\text { waste for shipment to WIPP. }\end{array}$ \\
\hline Drum Coring & $\begin{array}{l}\text { To physically sample the contents of a container (drum or box) using a coring device } \\
\text { that penetrates the surface of the container and extracts a portion of the contents. }\end{array}$ \\
\hline Drum Venting & $\begin{array}{l}\text { Relieving a container of waste of its internal pressure; or, for purposes of headspace } \\
\text { gas sampling, puncturing the surface of the container. }\end{array}$ \\
\hline $\begin{array}{l}\text { Fourier Transform } \\
\text { Infrared Spectroscopy } \\
\text { (FTIR) }\end{array}$ & $\begin{array}{l}\text { Method for determining VOCs and methane in headspace gas samples based on } \\
\text { absoption spectroscopy in the mid-infrared region }\left(200-4,000 \mathrm{~cm}^{-1}\right) \text {. }\end{array}$ \\
\hline $\begin{array}{l}\text { Gamma Ray Energy } \\
\text { Analysis }\end{array}$ & $\begin{array}{l}\text { The spectrometric characterization of a sample used to determine its radionuclide } \\
\text { content. In this technique emitted gamma photon intensity is measured as a function } \\
\text { of discrete gamma energies emitted by the sample. }\end{array}$ \\
\hline Gamma Scanning & $\begin{array}{l}\text { To create an image of a sample using the gamma photons emitted from radionuclides } \\
\text { within the sample. The image is formed by placing the sample in front of a collimated } \\
\text { high-sensitivity gamma detector. }\end{array}$ \\
\hline Gamma Spectroscopy & $\begin{array}{l}\text { The analysis of a gamma ray spectrum to identify the radioisotopes present in a waste } \\
\text { sample. }\end{array}$ \\
\hline Hazardous Waste & $\begin{array}{l}\text { As defined by RCRA, a solid waste, or combination of solid wastes, that because of } \\
\text { its quantity, concentration, or physical, chemical, or infectious characteristics may } \\
\text { cause or significantly contribute to an increase in mortality. A list of RCRA } \\
\text { hazardous wastes is found in } 40 \text { CFR part } 261 \text {. }\end{array}$ \\
\hline HEPA Filter & $\begin{array}{l}\text { A high-efficiency particulate air filter used in various applications that require the } \\
\text { retention of particles larger than } 0.2 \text { microns. Has an efficiency of at least } 99.999 \% \text {. }\end{array}$ \\
\hline
\end{tabular}




\begin{tabular}{|c|c|}
\hline Term & Definition \\
\hline $\begin{array}{l}\text { Inductively Coupled } \\
\text { Plasma (ICP) }\end{array}$ & $\begin{array}{l}\text { A means for delivering a sample stream to instruments such as atomic emission } \\
\text { spectrometers or mass spectrometers to analyze the waste content. In the ICP unit, } \\
\text { radio frequency power is inductively coupled into an argon sweep gas, heating the } \\
\text { argon gas to } 5,000-10,000 \mathrm{~K} \text { and ionizing the sweep gas. When the sample is injected } \\
\text { into the ionized sweep gas, usually as an aqueous solution or fine solid dispersion, the } \\
\text { sample is in turn heated, atomized, and excited or ionized. }\end{array}$ \\
\hline Interrogation & $\begin{array}{l}\text { The use of an active external probe to measure a signal from a passive sample. The } \\
\text { term is usually used in the context of prompt or delayed neutron interrogation, } \\
\text { wherein a neutron response is stimulated in the sample using a neutron accelerator or } \\
\text { isotopic source. }\end{array}$ \\
\hline Laser Ablation & $\begin{array}{l}\text { A process that uses a laser beam to remove layers of material through erosion or } \\
\text { disintegration. }\end{array}$ \\
\hline Linear Diode Array & $\begin{array}{l}\text { A linear array, or string, of diode detectors used in computed tomography as the } \\
\text { detector for the imaging process. }\end{array}$ \\
\hline $\begin{array}{l}\text { Low-Level Waste } \\
\text { (LLW) }\end{array}$ & $\begin{array}{l}\text { Typically, discarded material such as rags, construction rubble, glass, etc. that is only } \\
\text { slightly or moderately radioactive. LLW is typically characterized by short-lived } \\
\text { isotopes and, as the name suggests, low activity. }\end{array}$ \\
\hline Mass Spectrometer & $\begin{array}{l}\text { Also mass spectrograph. A device in which molecules are ionized and the accelerated } \\
\text { ions are separated according to their mass-to-charge ratio. }\end{array}$ \\
\hline Mobile System & In a trailer or capable of being mounted in a trailer. \\
\hline Neutron Examination & $\begin{array}{l}\text { Characterization of a waste sample using a neutron probe. This technique uses either } \\
\text { neutron interrogation to determine total fissile material content or neutron } \\
\text { radiography. }\end{array}$ \\
\hline $\begin{array}{l}\text { Nondestructive Assay } \\
\text { (NDA) }\end{array}$ & $\begin{array}{l}\text { Quantitative analysis of a particular constituent of waste within a container that does } \\
\text { not violate the integrity of the seal. }\end{array}$ \\
\hline $\begin{array}{l}\text { Nondestructive } \\
\text { Examination (NDE) }\end{array}$ & $\begin{array}{l}\text { Qualitative examination of waste matter to determine the presence of free liquids and } \\
\text { compressed gas container and to verify waste matrix and inner confinement layers } \\
\text { without violating the seal of the container. }\end{array}$ \\
\hline $\begin{array}{l}\text { Passive Active Neutron } \\
\text { (PAN) Interrogation }\end{array}$ & $\begin{array}{l}\text { The determination of total fissile material content of a sample by neutron emission } \\
\text { analysis. In the passive mode, characterization depends on the self-emission of } \\
\text { neutrons from the fissile radionuclides in the sample. In the active interrogation } \\
\text { mode, characterization depends on the use of an external flux (or probe) such as a } \\
\text { neutron beam from an accelerator or from a neutron-emitting isotope (such as Am-Be, } \\
\text { Cf-252) to stimulate neutron production by the sample. }\end{array}$ \\
\hline Portable & Capable of being easily modified to fit into a trailer. \\
\hline $\begin{array}{l}\text { Preparation of TRU } \\
\text { Waste }\end{array}$ & $\begin{array}{l}\text { In this plan the term is used interchangeably with processing to encompass functions } \\
\text { leading to certification and shipment of TRU waste: characterization, treatment, } \\
\text { repackaging, and loading into shipping containers. }\end{array}$ \\
\hline Privatization & $\begin{array}{l}\text { Procurement of services or products from commercial vendors through fixed-price } \\
\text { competition for contracts. Payment is rendered when services or products are } \\
\text { delivered. }\end{array}$ \\
\hline
\end{tabular}




\begin{tabular}{|c|c|}
\hline Term & Definition \\
\hline $\begin{array}{l}\text { Processing of TRU } \\
\text { Waste }\end{array}$ & $\begin{array}{l}\text { In this plan the term is used interchangeably with preparation to encompass functions } \\
\text { leading to certification and shipment of TRU waste: characterization, treatment, } \\
\text { repackaging, and loading into shipping containers. }\end{array}$ \\
\hline Prompt Gamma Neutron & $\begin{array}{l}\text { A characterization process that uses neutron or gamma interrogation to elicit a prompt } \\
\text { gamma and/or a prompt neutron emission from the sample to identify the presence of } \\
\text { certain high cross-section nuclides (as organic or inorganic materials) or to quantify } \\
\text { the total fissile content of the sample. }\end{array}$ \\
\hline QAPP & $\begin{array}{l}\text { The Quality Assurance Program Plan defines the data quality objectives that govern } \\
\text { characterization of TRU waste. }\end{array}$ \\
\hline Radiography & $\begin{array}{l}\text { A nondestructive testing method that uses } x \text {-rays to inspect and determine the } \\
\text { physical form of waste. The technique depends on unique } x \text {-ray absorption } \\
\text { characteristics of materials, i.e., the mass absorption coefficients of the constituent } \\
\text { elements, the physical density, and the geometric thickness of the sample. }\end{array}$ \\
\hline $\begin{array}{l}\text { Real-Time Radiography } \\
\text { (RTR) }\end{array}$ & $\begin{array}{l}\text { A nondestructive, nonintrusive examination technique for qualitative (and in some } \\
\text { cases semiquantitative) evaluation of the contents of a waste container. RTR uses x- } \\
\text { rays to inspect the contents of the waste container and allows the operator to view } \\
\text { events in real time. }\end{array}$ \\
\hline $\begin{array}{l}\text { Residual Gas Analyzer } \\
\text { (RGA) }\end{array}$ & $\begin{array}{l}\text { An instrument for identifying the gas or gas mixture in a sample, a container, or the } \\
\text { environment in a system. The active component of a RGA is most often a mass } \\
\text { spectrometer of unit resolution and limited mass range. }\end{array}$ \\
\hline $\begin{array}{l}\text { Segmented Gamma } \\
\text { Scanner }\end{array}$ & $\begin{array}{l}\text { A gamma assay technique that characterizes the gamma-emitting radionuclide content } \\
\text { of a sample. The scanner collects the gamma ray spectrum from slices, or segments, } \\
\text { of the sample; the gamma emissions from a given segment of a sample are integrated } \\
\text { to yield the radioisotopic composition of that segment. }\end{array}$ \\
\hline Shuffler & $\begin{array}{l}\text { A delayed neutron interrogator that uses a retractable neutron source to irradiate the } \\
\text { sample. Because the retractable source needs to be lightweight, the neutron source is } \\
\text { most often a neutron-emitting radioisotope. Shufflers are used to characterize a } \\
\text { sample for the total fissile material content. }\end{array}$ \\
\hline $\begin{array}{l}\text { Standard Waste Box } \\
\text { (SWB) }\end{array}$ & $\begin{array}{l}\text { USA DOT 7A Type A metal container ( } 38 \text { " high } \times 71^{\prime \prime} \text { wide } \times 55^{\prime \prime} \text { long) with a } \\
\text { design weight of } 3,500 \text { pounds loaded (box and waste). This box is a container for } \\
\text { TRU waste that can be loaded into a TRUPACT-II for transport to WIPP. }\end{array}$ \\
\hline Trailer & $\begin{array}{l}\text { A transportation device used to physically move characterization equipment from one } \\
\text { location to another with little or no impact on the operational stability and accuracy of } \\
\text { the instruments. This device consists of an instrument section, the control room, } \\
\text { conveyance, utility hook ups, and a HEPA filtration system. }\end{array}$ \\
\hline TRAMPAC & $\begin{array}{l}\text { A site-specific document of TRU waste content codes which describe the contact- } \\
\text { handled TRU waste material in terms of processes and packaging. This provides an } \\
\text { assessment of the wastes' qualification as payload for the TRUPACT-II package. }\end{array}$ \\
\hline TRUPACT-II & $\begin{array}{l}\text { Containers that will be used to ship TRU waste. They are certified by the U.S. } \\
\text { Nuclear Regulatory Commission through a rigid series of tests to ensure that they will } \\
\text { maintain their leak-tight integrity during a highway incident. }\end{array}$ \\
\hline
\end{tabular}




\begin{tabular}{|l|l|}
\hline \multicolumn{1}{|c|}{ Term } & \multicolumn{1}{c|}{ Definition } \\
\hline $\begin{array}{l}\text { TRUPACT-II Mobile } \\
\text { Loading Unit }\end{array}$ & $\begin{array}{l}\text { A device custom-designed to load and unload the TRUPACT-II at remote locations } \\
\text { where conventional loading devices are not available. }\end{array}$ \\
\hline $\begin{array}{l}\text { Transuranic (TRU) } \\
\text { Waste }\end{array}$ & $\begin{array}{l}\text { Waste that is contaminated with alpha-emitting radionuclides with an atomic number } \\
\text { greater than } 92 \text { (heavier than uranium), half-lives greater than 20 years, and } \\
\text { concentrations greater than } 100 \mathrm{nCi} / \mathrm{g} .\end{array}$ \\
\hline $\begin{array}{l}\text { Vendor Quality } \\
\text { Assurance Document }\end{array}$ & $\begin{array}{l}\text { Details how a mobile system operation and resuitant data will meet applicable QAPP } \\
\text { requirements. }\end{array}$ \\
\hline $\begin{array}{l}\text { Volatile Organic } \\
\text { Compound (VOC) }\end{array}$ & $\begin{array}{l}\text { Gases listed in Tables 12-1 and 13-1 of the QAPP. Also includes compounds } \\
\text { tentatively identified by the VOC analytical procedures used to satisfy WIPP program } \\
\text { requirements. }\end{array}$ \\
\hline $\begin{array}{l}\text { Waste Inspection } \\
\text { Tomography }\end{array}$ & $\begin{array}{l}\text { Techniques for making x-ray images of a predetermined plane section of a waste } \\
\text { container containing solid objects by blurring out the images of other planes. }\end{array}$ \\
\hline
\end{tabular}




\section{REFERENCES}

DOE 1991, Unreviewed Safety Questions, DOE Order 5480.21.

DOE 1994, Mixed Waste Treatment Plan, DOE-Albuquerque Operations Office.

DOE 1995, Transuranic Waste Characterization Quality Assurance Program Plan, Revision 0, CAO-94-1010, DOE-Carlsbad Area Office.

DOE 1995, Contact-Handled Transuranic Waste Characterization Systems Analysis, DOE-Carlsbad Area Office.

DOE 1995, Performance Demonstration Program Plan for Nondestructive Assay for the TRU Waste Characterization Program, Revision 0, DOE/CAO-94-1045, DOE-Carlsbad Area Office.

DOE 1995, Performance Demonstration Program Plan for the Analysis of Simulated Headspace Gases for the TRU Waste Characterization Program, Revision 0, DOE/CAO-95-1076, DOE-Carlsbad Area Office.

DOE 1995, DOE Waste Treatability Group Guidance, Revision 0, DOE/LLW-217.

DOE 1995, Transuranic Waste Baseline Inventory Report, Revision 2, CAO-95-1121, DOE-Carisbad Area Office.

DOE 1996, Waste Acceptance Criteria for the Waste Isolation Pilot Plant, Revision 5, DOE/WIPP-069, DOE-Carlsbad Area Office.

DOE 1996, Performance Demonstration Program Plan for RCRA Constituent Analysis of Solidified Wastes, Revision 1, DOE/CAO-95-1077, DOE-Carlsbad Area Office.

DOE 1996, National Transuranic Waste Management Plan, Revision 0, DOE/NTP-96-1204, DOE-Carlsbad Area Office.

DOE 1996, DOE-CAO Quality Assurance Program Document, Revision 1, CAO 94-1012, DOE-Carisbad Area Office.

DOE 1996, Transuranic Waste Characterization Sampling and Analysis Methods Manual, Revision 1.0, DOEWIPP-91-043, DOE-Carlsbad Area Office.

Final Report: Feasibility Study on the Modular Treatment for Plutonium Residue Stabilization, Los Alamos National Laboratory, LA-CP-95-296, 1996.

Mobile Waste Characterization Systems Analysis Report, DOE-Carlsbad Area Office, NTP-WID-96-2163, 1996.

Mobile Nondestructive Assay and Examination Instruments, J. M. Bieri and J.T. Caldwell, LA-UR-86-2189, 1986.

Use of Mobile Systems for Waste Characterization, National TRU Program Technical Position, draft, Revision 1, 1996.

Waste Management Facilities Cost Information for Transuranic Waste, Revision 1, Shropshire et al., INEL-95/0015, 1995. 


\section{Appendix A}

\section{CARLSBAD AREA OFFICE}

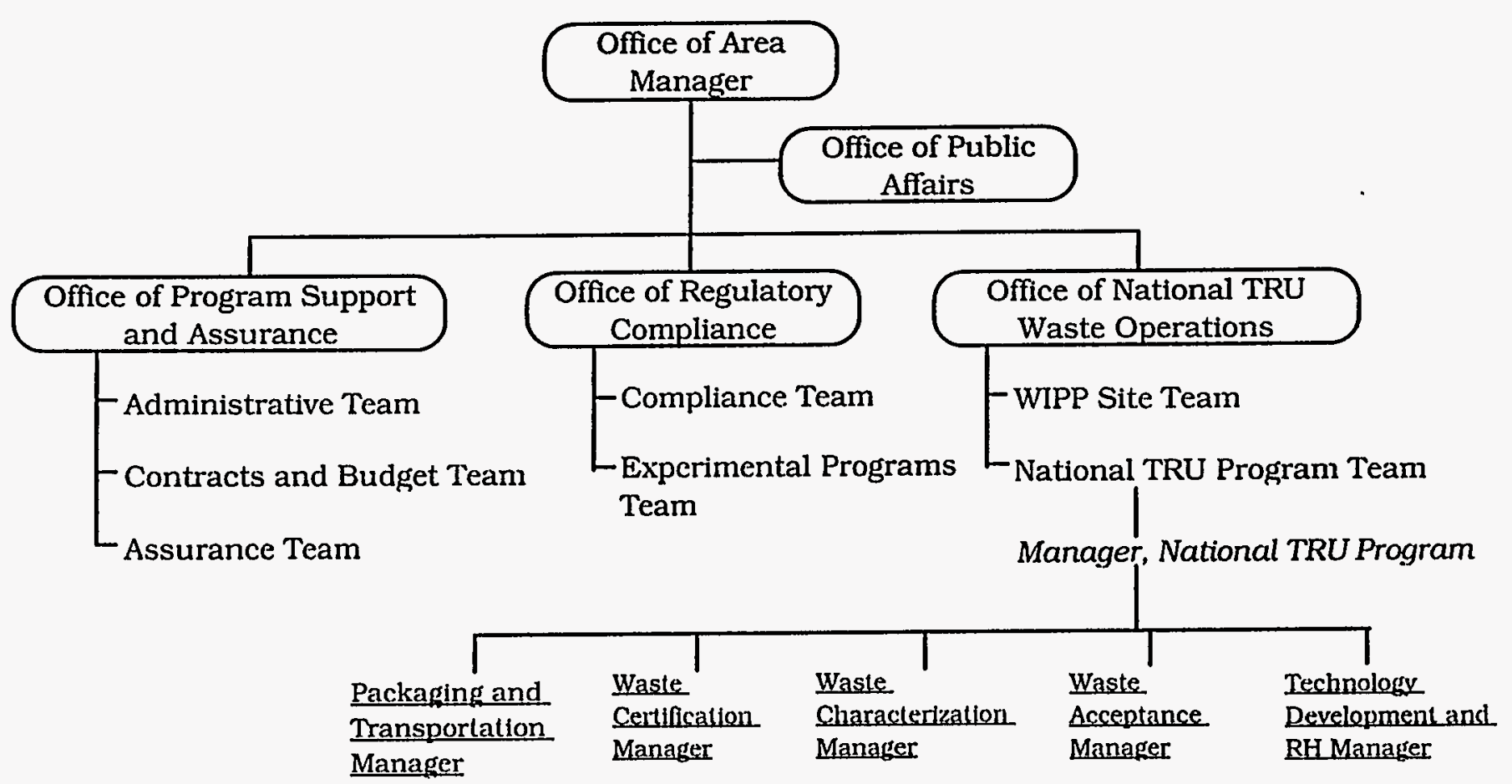




\section{Inventories of Contact-Handled TRU Waste*}

\begin{tabular}{|c|c|c|c|}
\hline Site & $\begin{array}{l}\text { Stored Volumes** } \\
\text { (Cubic Meters) }\end{array}$ & $\begin{array}{c}\text { Projected } \\
\text { Volumes }\end{array}$ & $\begin{array}{c}\text { Anticipated } \\
\text { Volumes }\end{array}$ \\
\hline Hanford (Richland) Site & 16,407 & 9,251 & 25,658 \\
\hline Idaho National Engineering Laboratory & 65,102 & 81 & 65,183 \\
\hline Los Alamos National Laboratory & 7,770 & 9,259 & 17,029 \\
\hline Rocky Flats Environmental Technology Site & 1,043 & 14,741 & 15,784 \\
\hline Savannah River Site & 9,165 & 3,773 & 12,938 \\
\hline Lawrence Livermore National Laboratory & 249 & 905 & 1,154 \\
\hline Nevada Test Site & 623 & 12 & 635 \\
\hline Oak Ridge National Laboratory & 1,303 & 256 & 1,559 \\
\hline Argonne National Laboratory - East & 83 & 12 & 95 \\
\hline Mound Plant & 239 & 12 & 251 \\
\hline \multicolumn{4}{|l|}{ Small Quantity Sites } \\
\hline Ames Laboratory & 0 & $<1$ & $<1$ \\
\hline Bettis Atomic Power Laboratory & 0 & 123 & 123 \\
\hline Energy Technology Engineering Center & 2 & 0 & 2 \\
\hline Paducah Gaseous Diffusion Plant & 2 & 0 & 2 \\
\hline Pantex Plant & $<1$ & 0 & $<1$ \\
\hline Sandia National Laboratories - Albuquerque & 7 & 6 & 13 \\
\hline Teledyne Brown & $<1$ & 0 & $<1$ \\
\hline U.S. Army Material Command & 3 & 0 & 3 \\
\hline University of Missouri Research Reactor & $<1$ & $<1$ & $<1$ \\
\hline ARCO Medical Products Company & $<1$ & 0 & $<1$ \\
\hline General Electric - Vallecitos Nuclear Center & 5 & 4 & 9 \\
\hline Babcock \& Wilcox-Lynchburg & 18 & 0 & 18 \\
\hline Lawrence Berkeley Laboratory & $<1$ & 1 & 1 \\
\hline Total Volume & 102,021 & 38,437 & 140,458 \\
\hline
\end{tabular}

*National Transuranic Waste Management Plan

**Volumes prior to treatment and repackaging 


\section{Appendix C}

\section{MOBILE SYSTEMS CAPABILITY CHECKLIST}

Vendor/Site:

Contact:

Name:

Department:

Address:
Date:

Phone:

FAX:

Sampling and/or characterization capability (For example, NDA, NDE, Headspace Gas Analysis, Drum Venting and Filter Insertion, Coring, Repackaging/Visual Inspection, total metal analysis, VOC analysis, Semi-VOC analysis)

Equipment Description (For example, if the capability is NDA, is the equipment segmented gamma, does it have isotopic analysis capability, etc.?)

For Chemical and Radiological Data:

Which WIPP Rqmt?

Contaminant
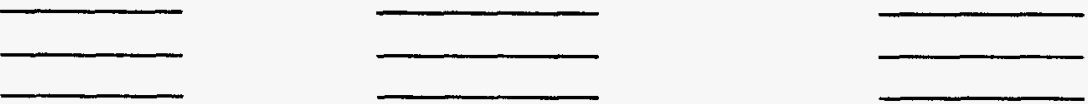

For Physical Data:

Which WIPP Rqmt?

Compliance with

Waste Matrix
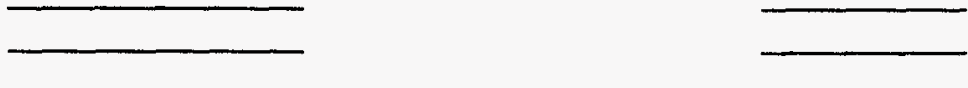

Equipment Status (For example, is it commercially available now, is it in the design stage, has it undergone field testing with TRU waste, is it already mobile [in a trailer], or transportable [on skids]?)

Equipment Cost $(\$ \mathrm{~K})$ :(excluding taxes and shipping costs, but including a description of features for the cost) 
Equipment Delivery Schedule: (how long after the date of contract will the equipment be acceptance tested and delivered for procurement or fieiding time for a service contract?) Acceptance Tested

Delivered/fielded:

Estimated Size of Operating Crew: (persons)

Estimated Yearly Operating Cost:(assuming one shift per day at five days per week operating at full capacity) (\$K/year)

Estimated Yearly Maintenance Cost (assuming one shift per day at five days per week operating at full capacity) $(\$ K /$ year $)$

\section{Estimated Time to Set Up Mobile System:}

Estimated Time to Break Down Mobile System:

Estimated Lifetime: (time elapsed when replacement is required, assuming operation was sustained at one shift per day for five days per week at full capacity) (years)

Estimated Processing Rate for 55-Gallon Drums: (Note: Specify the waste matrix)

Rate (drums/hour)

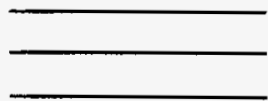

\section{Waste Matrix}

\section{Waste Matrix}

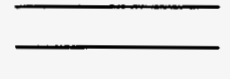

If the equipment is in a trailer, is the trailer configured as a Type A container (DOT, 49CRF 178.350)?

Is the equipment and/or trailer (if applicable) vented into a HEPA filtration?

Equipment? Trailer?

Is there a Carlsbad Area Office, DOE-approved QAPjP for the operation of this equipment? Is this method of sampling and/or characterization validated as meeting the WIPP Quality Assurance Objectives through participation in the Carlsbad Area Office, DOE Performance Demonstration Program, if applicable?

Is the characterization data from the analysis of TRU waste using this equipment reported in a format that can be used for the WTPP data package? (i.e., for NDA results, are results reported as Pu-239 Fissile Gram Equivalents, Pu-239 Equivalent (PE) Activity, Thermal Power, and TRU Alpha Activity, Decay Heat as well as concentrations of the TRU isotopes?)

Is the equipment (and trailer, if applicable) readily decontaminated if contamination should occur? 